Sultan Qaboos University Journal of Arts \& Social Sciences

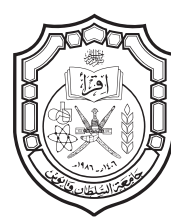

جامعة السلطان قابوس الإدام مجلة الآداب والعلوم الاجتمأعية

\title{
الأنماط القيادية بالمدارس الحكومية بمحافظة عجلون وعلاقتها بالأداء المتميز للمديرين من وجهة نظر المعلمين
}

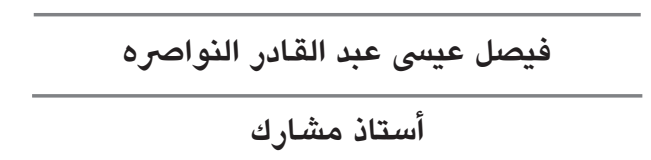

قسم التربية الخاصة - كلية الآداب والعلوم التربوية جامعة عجلون الوطنية

nawasrehf@yahoo.com

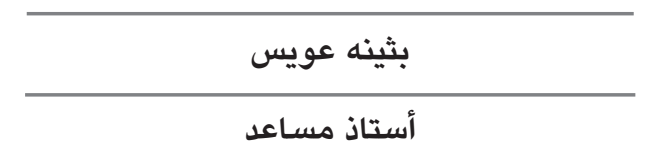

قسم متطلبات الجامعة - كلية الآداب والعلوم التربوية جامعة عجلون الوطنية nanaawais@hotmail.com 


\section{الأنماط القيادية بالمدارس الحكومية بمحافظة عجلون \\ وعلاقتها بالأداء المتميز للمديرين من وجهة بادئ نظر المعلمين}

بثينه عويس، فيصل عيسى عبد القادر النواصره

هدفت هذه الدراسة إلى الكشف عن الأنماط القيادية لمديري المدارس في محافظة عجلون وعلاقتها بـالأداء المتميز لديهم من وجهة نظر المعلمين،

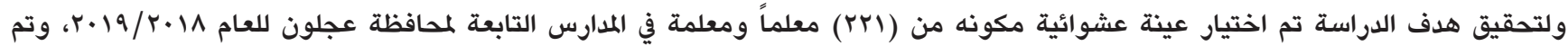

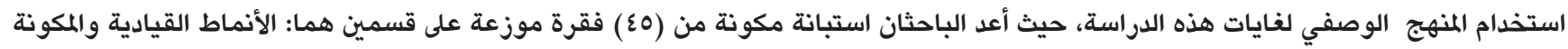

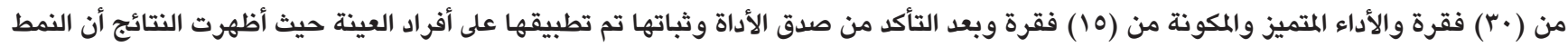

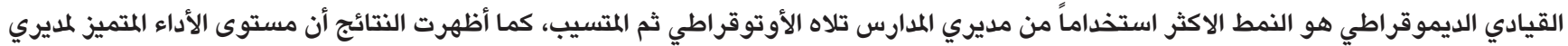

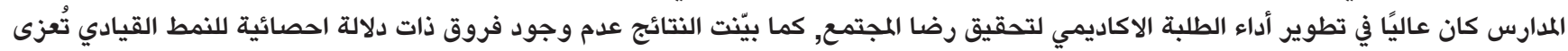

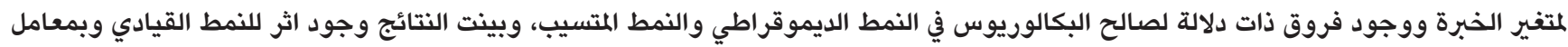

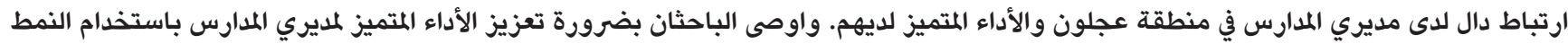

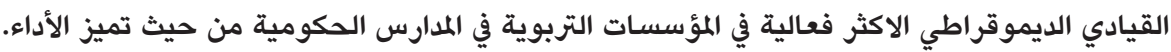

الكلمات المفتاحية: القيادة، النمط القيادي، الديمقراطي، الأداء المتميز.

\section{The prevailing leadership styles among the principals of public schools and their relationship to their outstanding performance}

Bothina Owais, Faisal Issa A'Qader Alnawasreh

\section{Abstract}

The aim of this study was to disclose the dominant leadership patters of school principals in Ajloun governorate and their relationship with their outstanding performance from the teachers' point of view. To achieve the study objectives, the researchers used a questionnaire consisting of (45) paragraphs divided into two categories: leadership styles with 30 paragraphs and outstanding performance (15), The sample consists of (221) teachers were selected randomly from the schools of Ajloun of the year 2019/2018. After verifying the validity of the tool and its stability, it was applied to the sample. The results showed that the democratic leadership style is the most used from the principles of the schools, then the autocratic, after that the careless style. The results also showed that the level of the best performance of the school principals was high at the developing of academic performance of students and there weren't any statically differences at the leadership style in favor to the experience variable, and there were statically differences in favor of the bachelor in the democratic style and the careless style. And the results showed that there was a positive correlation between the leadership style of school principals and their outstanding performance. The results were discussed in the light of the theoretical framework \& previous studies, it was suggested some recommendations on the basis of the results of the study. The researchers recommended that it's necessary to enhance the outstanding performance of school principals using the most effective democratic leadership style in educational institutions in public schools according to the performance excellence.

keywords: Leadership; Leadership Style; Democratic; Outstanding Performance. 


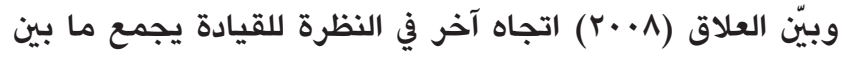
النظرة السلوكية والموقفيه بما يسمى بالتفاعلية والذي جمع بين الاتجاهين السابقين، ويطلق عليها أصحابها أيضاً (النظرية والية التوافقية)، وتقوم هذه النظرية على فكرة المـزج بين متغيرات

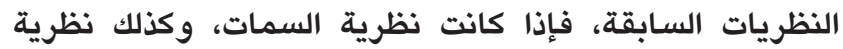
الرجل العظيم ترجـح القيادة إلى شخصية القائد، وأن نظرية الموقف تفسر القيادة من خلال الجماعة، فـإن النظريــة التفاعلية تقوم على أساس التكامل بين كل العوامل التي تؤثر في القيادة، فالقيادة عملية تفاعـل مع جميع الظروف، والعناصر المحيطة من بشرية، واجتماعية، ومادية، ووظيفيـة، وتعطـي النظرية

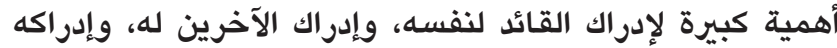

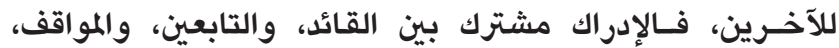
والوظائف وتقوم هذه النظرية على أساس التكامل، والتفاعل بين

المتغيرات الرئيسة الآتية:

أ. شخصية القائد، ودوره في الجماعة. ب. الجماعة التي يقودهم من حيث أهدافهم، وخصائصهم، وحاجاتهم، واتجاهاتهم.

ج. العلاقة القائمة بين القـائد، والجماعة. والمها. د. المواقف من حيث طبيعتها، وظروفها، والعوامل المادية المحيطة

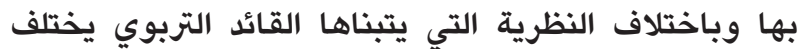
كذلك النمط القيادي الذي يتبناه وعلى هذا فبإن هذه الممارسات والتصرفات التي تضفي على إدارات هذه المدارس طابعاً أو نمطاً معيناً يجعلها تتصف بصفات وتتميز بخصائص معينة

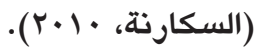

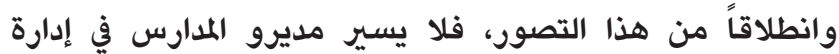

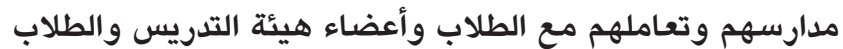
والعاملين في المدرسة على نمط واحد في الإدارة، وإنما يختلفون في تعاملهم الشخصي والمهني وفي إجراءاتهم ووسائلهم الإدارية باختلاف فلسفاتهم التربوية من جهة واختلاف إعدادهم وتدريبهم واتساع خبراتهم ونظرتهم إلى الإدارة من جهة أخرى (فهمي؛

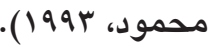

وأجمعت المراجع العربية والأجنبية في الإدارة المدرسية على تصنيف

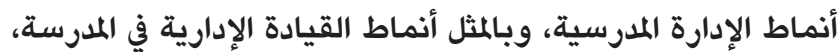

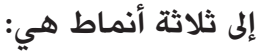

الجدول (1) سمات القائد المتميز الرئيسة وما يوازيها من مهارات لازمة

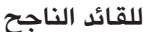

\begin{tabular}{|c|c|}
\hline 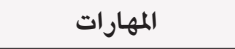 & السمات \\
\hline المهارات الفكرية & التكيف مع الوقت \\
\hline القدرة على الابداع & التفـاعل مـع الاحداث الاجتمـاعية \\
\hline اللباقة والدبلوماسية & الطموح \\
\hline 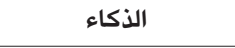 & الحزم التعـاون \\
\hline 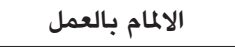 & القدرة على اتخاذ القرار \\
\hline 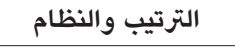 & 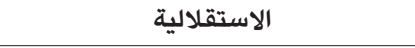 \\
\hline القدرة على الاقناع & 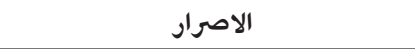 \\
\hline الذكاء الاجتماعي & تحمل ضغوط العمل وتحمل المسؤولية \\
\hline
\end{tabular}

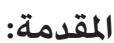

تنتظم مؤسساتنا التربوية وتتقدم نحو الهدف بخطى ثابته إذا ما حظيت بقادة متميزون يحققون الهدف المنشود بالعمل الدؤوب المبدع والمحفز، وبغياب هذه النماذج من القياديين نستطيع القول أن الادارة عجزت عن تحقيق اهدافها المرسومة والمحددة وبالتالي الوصول بالعملية التعليمية الى المستوى الذي يؤهلها لمواكبة كل جديد في ظل التفيرات المتسارعة والتطور العلمي الذي نشهده في

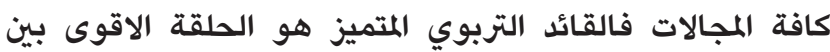
عناصر العملية التعليمية فهو الموجه والمحفز، ويمارس نمط قيادي يساعده في توجيه الجميع نحو الهدف، ويدفع بمؤسسته التربوية نحو التميز والإبداع لتصبح تجربته الإدارية نموذجًا

يُحتذى ويشار لها بالبنان.

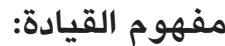

تُعرّف القيادة بأنها السمات التي من الممكن أن يتحلى بها من يتخذ دور القائد وقد عرّفها التربويون كلاً حسب النظرية التي يتبناها في الإدارة، فالتقليديون عرفوها أنها سلطة تمارس من قائد يمارس السيطرة على الناس والقيادة هي قدرة القائد للتأثير

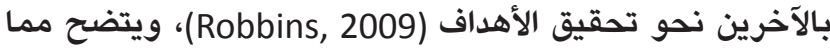
سبق أن المفهوم التقليدي للقيادة هو قدرة القائد على التأثير

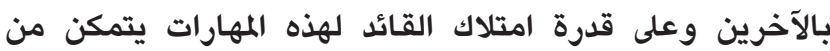
تحقيق الأهداف المشتركة. فقد عرف أصحاب النظرية السلوكية القيادة بأنها التأثير في الأشخاص وتوجيهم بطريقة تمكنهم من كسب طاعتهم

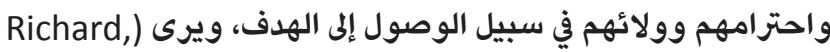
2008) أن القيادة من وجهة نظر سلوكية ليست بالسيطرة على فيلى الافراد والتحكم بهم ولكن العمل على إطلاق قدراتهم ومواهبهم.

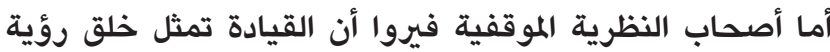
يتبعها الآخرين وتدفعهم للعمل باتجاهات مختلفة في مواقف مختلفة حيث عُرفت أنها عملية تجهيز وترتيب الموقف القيادي حتى يتمكن مختلف أعضاء الجماعة بما فيهم القائد من تحقيق

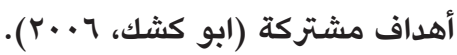
أما النظرة الحديثة للقيادة التربوية فهي القدرة على توضيح الرؤية الاستراتيجية للمؤسسة ودفع الآخرين للإيمان بها كما عرفها (Koontz \& Weirich, 1988)، كما عُرفت أنها علاقة لأنة التأثير بين القـادة والتابعين وإنها متعددة الاتجاهات، ويركز أصحاب هذه النظرية على ضرورة توفر بيئة تساعد على الابتكار والإبداع وتوفر قائد ملهم وموجه بشكل إيجابي، ومتمتع بعدد

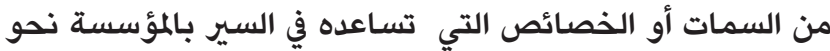

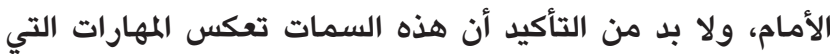
يمتلكها القائد التربوي وبالتالي النمط القيادي الذي يتبناه في إدارة المؤسسة التربوية الاكثر تفاعلاً مع الطلبة، والعاملين، وأولياء امور والمجتمع محلي، ويمكن حصر سمات القائد المتميز الرئيسة

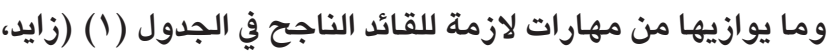

$:(r \cdot r$ 
مفهوم الأداء المتميز الأداء المتميز هو "قدرة المنظمة على الميز تحقيق أهدافها باستخدام الموارد بأسلوب فعال وكفؤ، وينبغي الأخذ بعين الاعتبار أن عملية الأنية الأنية

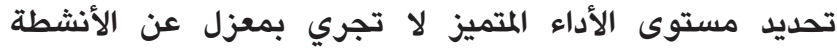

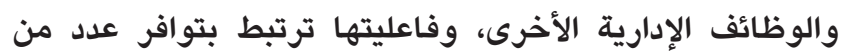

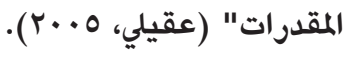

المفاهيم الأساسية للتميز تشمل المفاهيم الأساسية للتميز وفقاً لنموذج الأميز التميز الأوروبي

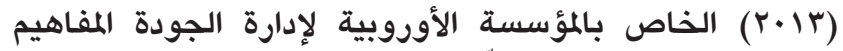

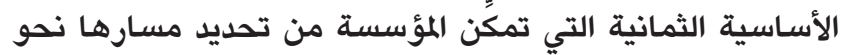

تحقيق أسس التميز وهذه المفاهيم هي:

ا - إضافة قيمة لصالح المتعاملين

تقوم المؤسسات المتميزة بإضافة قيمة لصالح المتعاملين معها

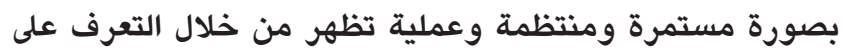

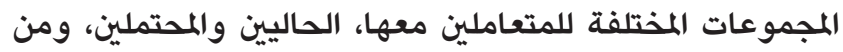
ثم التنبؤ باحتياجاتهم المختلفة وتوقعاتهم المستقبلية وترجمة كافة الاحتياجات إلى عروض قيمة مستدامة وجاذبة ولتية و بناء وتطوير حوار متوا صل مع المتعاملين يتسم بالشفافية والمصارحة

(Mohammad, Mann, Grigg \& Wagnera, 2011)

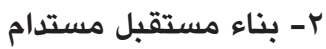
للمؤسسات المتميزة أثر إيجابي على العالم من حولها من خلال

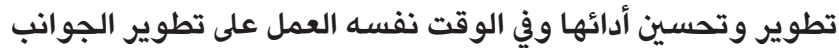

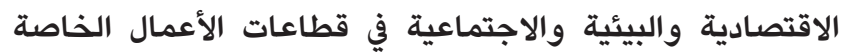
بها، وعملياً تقوم المؤسسات المتميزة بضمان مستقبل المؤسسة من خلال تحديد ونثر الغرض الأساسي الذي تستند إليه الرؤيا

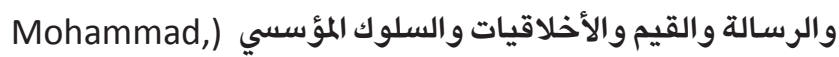

(etal, 2011

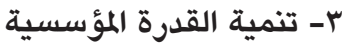
تقوم المؤسسات المتميزة ببناء وتطوير قدراتها من خلال الإدارة

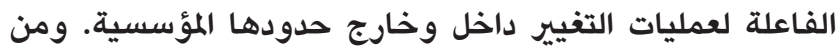

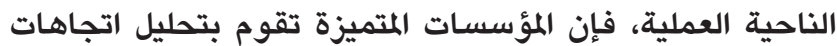

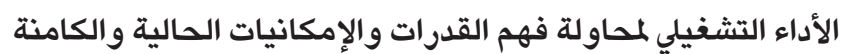
لديها، ومن ثم تحديد فرص التطوير والتحسين اللازمة لتحقيق التانيق

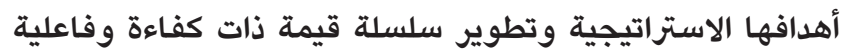
لضمان استدامة قدرة المؤسسة على الإيفاء بالتزاماتها الواردة في

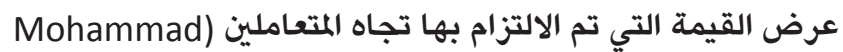

(\& etal, 2011

ع- تسخير الإبداع والابتكار تعزز المؤسسات المتميزة القيمة المضافة وتحقق مستويات متصاعدة الأداء من خلال آليات التحسين المستمر والابتكار المنتظم الذي يتحقق من خلال تسخير الإبداع لدى جميع المعنيين

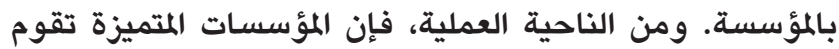

أولاً: النمط الأوتوقراطي: ان القائد في هذا النمط متسلط، يستأثر بجميع السلطات، ويرسم خطة العمل، ويحدد طرق تنفيذها،

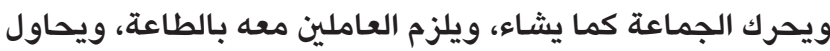

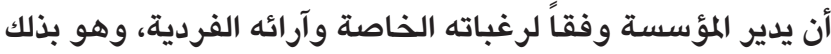

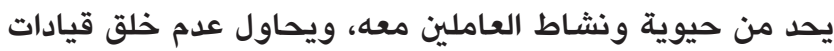

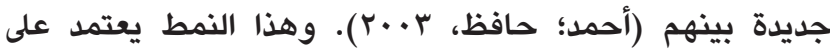
السلطة الرسمية في تسيير الأمور وعلى حرفية القوانين واللوائح

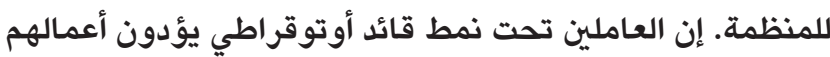

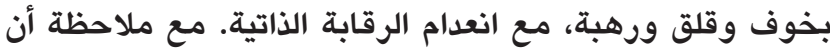

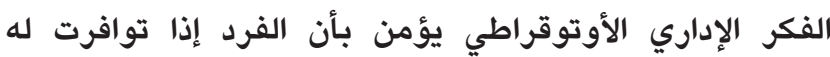

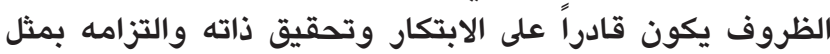

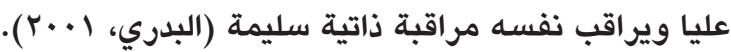
ثانياً: النمط الديموقراطي (Democratic): يتسم هذا النمط من

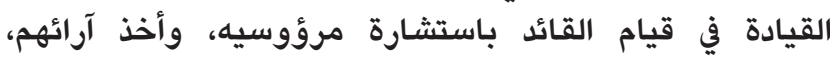

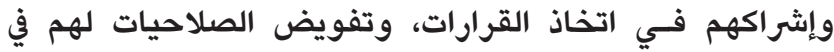

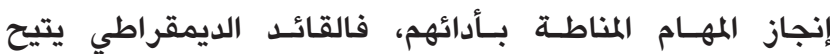

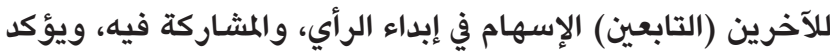

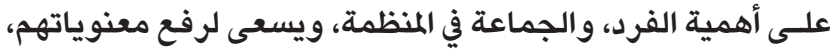

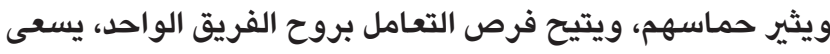

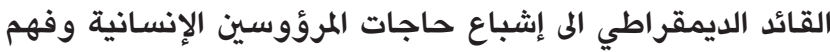

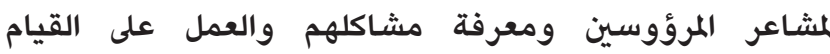

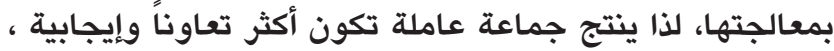

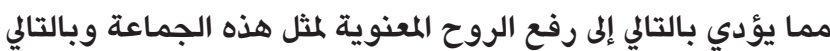

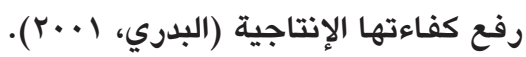

ثالثا: النمط المتسيب (The laissez -Fair Style) يطلق عليه

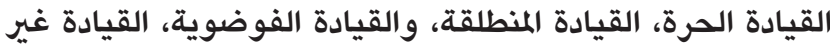
الموجهة، أوسياسة إطلاق العنان، أو نمط ترك الحبل المبادة على الغارب. وتقل فاعلية الأنظمة والقوانين واللوائح لدى القائد المتسيب لتحل التحل محلها الرغبات والنزعات دون تمييز، وتتحطم الحواجز والحاتئ والحدود

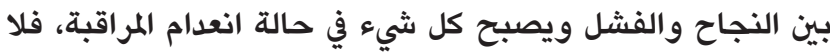
مسئولية ولا رقابة، بل اضطراب وتسيب وبلبلة وانعاب ولعدام الرؤية

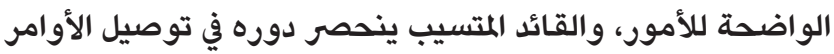
والإشارة إلى القوانين إلى المرؤوسين دون متابعة أو مراقبة (حمود،

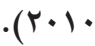

مما سبق يتضح أن اختلاف وسائل التفاعل بين القائد، والمرؤوسين بغرض توجيههم، وإرشادهم، هو من يعكس التباين في الأنماط

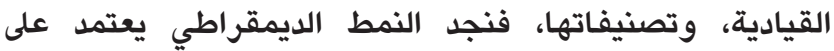

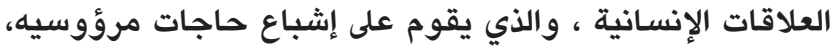

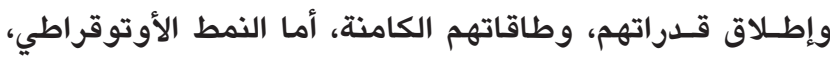
يقوم على الترهيب، والتخويف، ويكبح قدرات العاملين، أما فيما

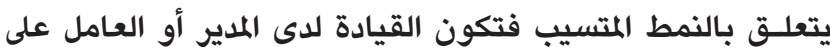

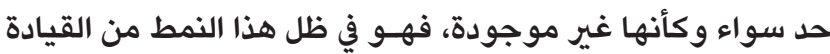

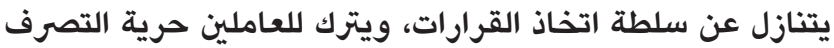

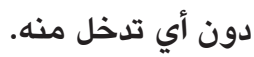




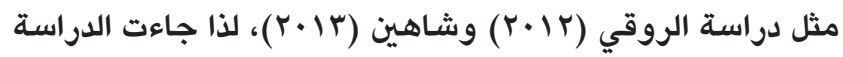
الحالية للكشف عن الأنماط القيادية بالمدارس الحكومية بمحافظة عجلون/ الأردن وعلاقاتها بالأداء المتميز للمديرين من وجهة نظاديه المعلمين، وتحاول الدارسة الإجابة عن التساؤلات الآتية: ا. ما الأنماط القيادية لمديري المدارس السائدة في المدارس المارس الإسها الحكومية للمرحلة الثانوية في محافظة عجلون من وجهة نظر لمارئرس

المعلمين؟

r. ما مستوى الأداء المتميز لدى مديري المدارس في المدارس الحكومية للمرحلة الثانوية في محافظة عجلون من وجهة نظمريز

المعلمين؟

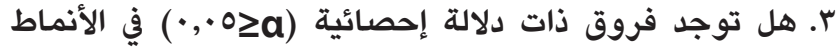
القيادية السائدة لمديري المدارس الحكومية دات للمرحلة الثانوية في عجلون تعزى لمتفيري سنوات الخبرة، الدرجة العلمية لملدير

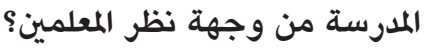

ع. هل توجد علاقة ارتباطية ذات دلالة احصائية عند مستوى الدلالة(0) لدى مديري المدارس الحكومية الثانوية في محافظة عجلون؟

أهداف الدراسة:

هدفت الدراسة الحالية الى الاتي: • الكشف عن الأنماط القيادية السائدة لمديري المدارس الحكومية الحية للمرحلة الثانوية في عجلون من وجهة نظر المعلمين.

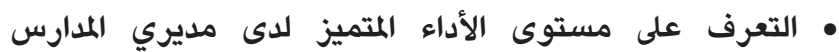
الحكومية للمرحلة الثانوية في محافظة عجلون من وجهة نظر

المعلمين.

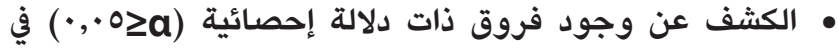
الأنماط القيادية السائدة لمديري المدارس الحكومية للمرحلة الثانوية في عجلون تعزى لمتفيري سنوات الخبرة، الدرجة العلمية لمدير المدرسة من وجهة نظر المعلمين. • الكشف عن العلاقة الارتباطية بين مستوى الأداء المتميز والنمط القيادي لدى مديري المدارس في محافظة عجلون من وجهة نظر المعلمين.

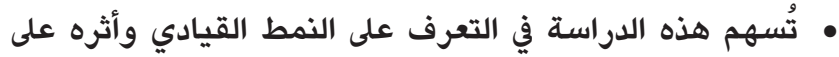
الأداء المتميز لدى العاملين في المؤسسات التعليمية.

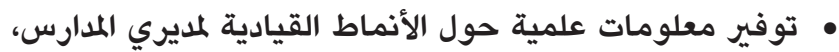
وانعكاساتها على الأداء المتميز لديهم.

أهمية الدراسة: - ماتص يعتبر القائد التربوي مدير المدرسة قائداً ناجحاً إذا ما كان يمتلك السلوك القيادي الداعم والمؤثر في الآخرين بهدف تحقيق الرسالة

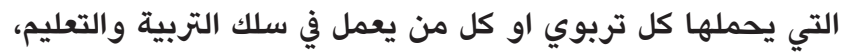
وهذا لن يتحقق إلا عند استخدام النمط القيادي الملائم لتحقيق

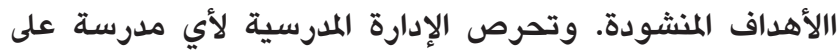
تحديد نوعية وكمية أداء عامليها للوقوف على أوجه القوة الأداه والضعف في مستوى الأداء بهدف تحقيق التميز الذي يسعى النظام
بصياغة منهجيات لإشراك المعنيين بالمؤسسة وتحقيق الاستخدام الأمثل للمعارف المتراكمة لديهم من خلال توظيفها لإنتاج الأفكار

والإبداع (Mohammad \& etal, 2011).

0- القيادة من خلال رؤيا وإلهام ونزاهة

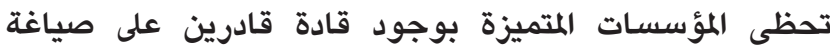
المستقبل وتحويله إلى واقع، كما يقومون أيضاً بإعطاء القدوة الحسنة في القيم والسلوكيات المؤسسية. ومن الناحية العملية، فإن قادة المؤسسات المتميزة يقومون بشحذ الهمم و السعي لخلق ثقافة الإشراك والحيازة والتمكين، والتحسين والمساءلة لجميع

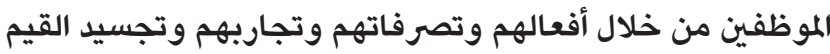
المؤسسية وإعطاء القدوة الحسنة في النزاهة والمسؤولية المجتمعية والسلوك المهني وصياغة مسار مستقبلي واضح. 7- الإدارة بمرونة وسرعة التكيف مع التغيير تعرف المؤسسات المتميزة بقدرتها على اغتنام الفرص ولهر المتاحة الفيرة ومجابهة التحديات الماثلة وسرعة التجاوب معها بالكفاءة والفـاعلية المطلوبة. ومن الناحية العملية، فإن المؤسسات المتميزة تقوم باستخدام الآليات المناسبة للتعرف على المتفيرات في البيئة الخارجية وترجمتها إلى سيناريوهات مستقبلية ممكنة وتطوير مجموعة من مؤشرات أداء العمليات ونتائج مخرجات الأعمال

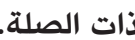

-V النجاح من خلال مواهب وقدرات موظفي المؤسسة

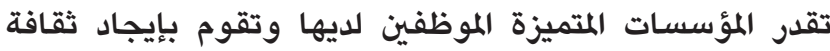
التمكين لهم من أجل تحقيق الأهداف الشخصية والمؤسسية. ومن الناحية العملية، فإن المؤسسات المتميزة تقوم بتحديد المهارئ المدارات والكفاءات ومستويات أداء الموظفين المطلوبة والتخطيط الفعال لجذب وتطوير المواهب والقدرات المطلوبة.

^- استدامة النتائج الباهرة تحقق المؤسسات المتميزة نتائج باهرة ومستدامة تلبي الاحتياجات الخاصة بجميع المعنيين بالمؤسسة، ومن الناحية العملية، فإن المؤسسات المتميزة تقوم بتجميع الاحتياجات الحالية والتوقعات المستقبلي، التطبيق المنتظم للاستراتيجية والسياسات الداعمة لها لتحقيق النتائج المنشودة مع التعريف الواضح لعلاقة السببية وأثر تقييم حزمة النتائج التي تم تحقيقها لأغراض تحسين المين الأداء المستقبلي وتوفير منافع مستدامة لجميع المعنيين بالمؤسسة وتحقيق أعلى مستويات الثقة للمعنيين من خلال تبنى الآليات الفاعلة الرامية لتفهم السيناريوهات المستقبلية (Mohammad

(\& etal, 2011

مشكلة الدراسة: تنبثق مشكلة الدراسة من تفاوت نتائج الدراسات التي تناولت الأنماط القيادية بالمدارس الحكومية بمحافظة عجلون وعلاقاتها بالأداء المتميز للمديرين من وجهة نظر المعلمين، ويظهر ذلك ذالك بوضوح في دراسة واختلاف مجتمع الدراسة والعينة لدى كل منها 
أنماط السلوك القيادي السائد بين المديرين هو النمط الديموقراطي

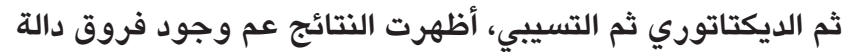

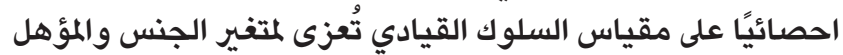
العلمي والخبرة التعليمية للمعلم ويوجد علاقة بين النمط القيادي و الاتجاه نحو التدريس.

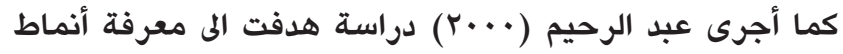
القيادة لدى مديري المدارس الأساسية وعلاقتها بالرضا الوظيفي للمعلمين من وجهة نظرهم، تكونت العينة من (VV0) معلماً

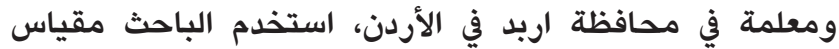
جوردن لوصف السلوك القيادي ومقياس مينسوتا لقياس الرضا الوظيفي، اشارت النتائج الى شيوع ثمانية أنماط للسلوك القيادي

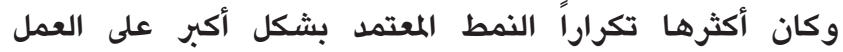

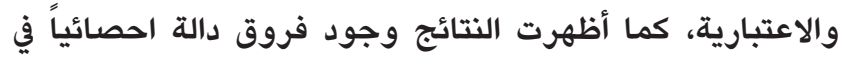
درجة الرضا الوظيفي لأنماط الإدارة المختلفة.

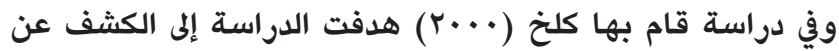

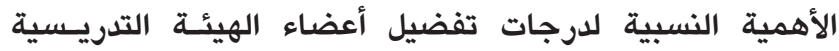

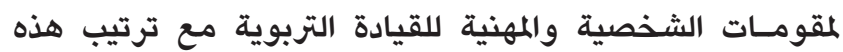

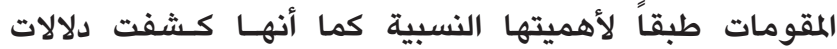
الفروق الاحصائية في درجات تفضيل أعضاء الهيئة التدريسية

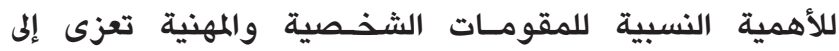
متغيرات (نوع الكلية، الدرجة العلمية، سنوات الخدمة، المؤسسة التـي يعمـل فيها الجامعة التي حصل منها على آخر مؤهل

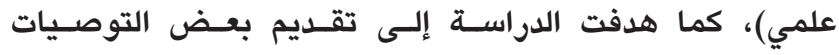

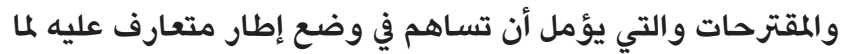

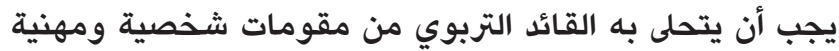

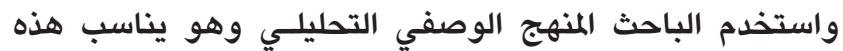
الدراسة وخصوصاً أن الباحث يصف ويحلل المقومات الشخصية والمهنية للقيادة التربوية.

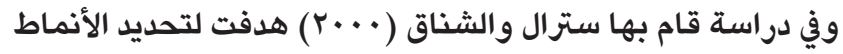
القيادية لمديري المدارس الثانوية الحكومية في الأردن من وجهة نظرهم وعلاقتها بالرضا الوظيفي، استخدم الباحثان استبانتين عن النمط القيادي والرضا الوظيفي، تكونت العينة من (0) معلمة، اشـارت النتائج الى أن مستوى الرضا الوظيفي للمعلمين والمعلمات كان مرتفعاً، كما تبين عدم وجود فروق بين الجنس مدان والمؤهل العلمي والخبرة في العلاقة بين النمط القيادي للمديرين

$$
\text { والرضا الوظيفي. }
$$

Moye, Henkin \& Egley,) وهدفت دراسة موي وهنكن وإجلي"

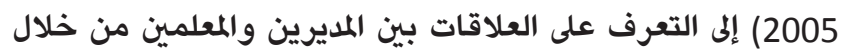
اكتشاف الروابط بين التمكين والثقة بين الأشخاص، وأظهرت

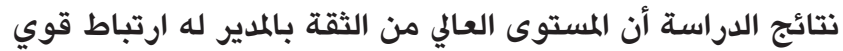

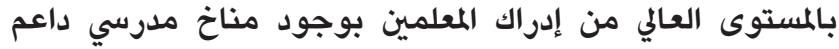

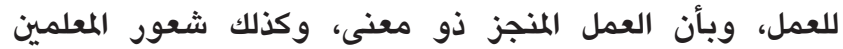
بالاستقلالية والمقدرة على التأثير في مناخ العمل. كما اجرى موليرو وآخرون (Molero \& etal, 2007) دراسة هدفت إلى مقارنة العلاقة بين القيادة التحويلية، وأنماط قيادية
التربوي الأردني لتحقيقه، وبما أن الأداء الوظيفي المتميز يتأثر

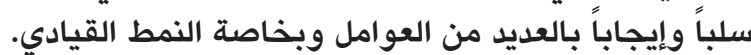

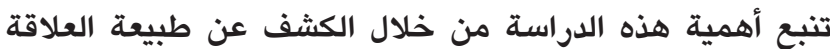
الارتباطية بين النمط القيادي لمديري المدارس والأداء المتميز في مئه المدارس الحكومية للمرحلة الثانوية في محافظة عجلون من وجهة الإئه نظر المعلمين ويمكن حصر أهمية هذه الدراسة بالعناصر الآتية:

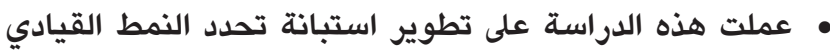
لمديري المدارس واستبانة تحدد مستوى الأداء المتميز وتم ايجاد الداد دلالات صدق وثبات لهما. الأنماط القيادية بالمدارس الحكومية الماءدية بمحافظة عجلون. • توضيح أهمية الكشف عن الأنماط القيادية بالمدارس الحكومية لما لها من علاقة وثيقة بالتنبؤ بالأداء المتميز للمديرين من

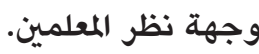

التعريفـات الاجرائية: القيادة هي "قدرة الفرد على التأثير على شخص أو مجموعة الثة من

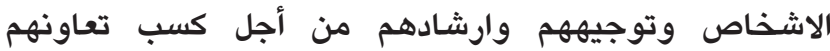
وتحفيزهم على العمل بأعلى درجة من الكفاءة في سبيل تحقيق

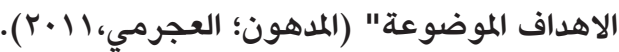
الانماط القيادية عرفها Robert Oens بأنها "السلوك الذي المدوفي يمارسه القـائد الفعال على أفراد المجموعة العاملة معه بهدف بادها

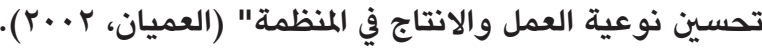
وتُعرّف اجرائياً: بانها الدرجة التي يتحدد من خلالها السلوك القيادي الذي يستخدمه المدير في مدرسته من وجهة نظر المعلمين من خلال استبانة النمط القيادي المستخدمة في الدراسة. الأداء المتميز: هو"السعي الدائم نحو التفوق والتقدم والإبداع في

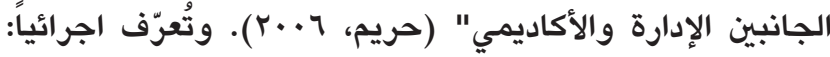

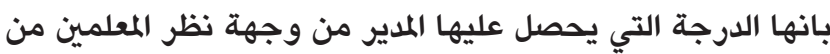
خلال استبانة الأداء المتميز المستخدمة في الدراسة.

حدود الدراسة ومحدداتها اقتصرت الدراسة الحالية على الحدود الآتية: ا. عينة من معلمي المدارس الحكومية في منطقة عجلون للعام $. r \cdot 19 / r \cdot 11$

r. يقتصر تعميم نتائج هذه الدراسة على الأداة التي استخدمها الباحثان (استبانة الأنماط القيادية واستبانة الأداء المتميز) وما تتمتع به كلا الاداتين من صدق وثبات.

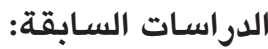
تم ايجاد بعض الدراسات في انماط القيادة التربوية والاداء المتميز وسيتم عرضها وفقا لتسلسلها الزمني من الأقدم إلى الأحدث. في دراسة قام بها شقير(1999) هدفت الى معرفة مستوى إدراك

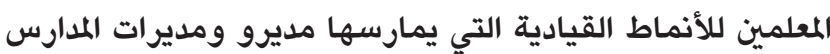
الحكومية وعلاقته باتجاهـاتهم نحو مهنة التدريس تكونت العينة

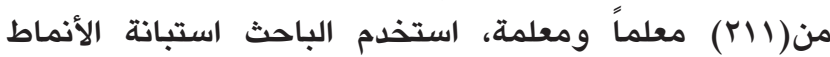

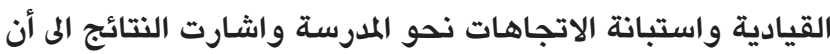


الأنماط القيادية السـائدة لدى مديري المــدارس الحكوميـة فـي محافظات غزة وعلاقتها بتعزيز ثقافة الإنجاز، وكذلك دراسة

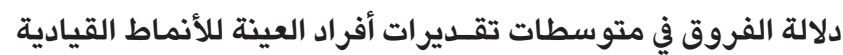
السائدة لدى مديريهم، ولدرجة ممارسة مديريهم لدورهم في تعزيز ثقافة الإنجاز بحسب متغيرات (الجنس، المؤهل العلمي،

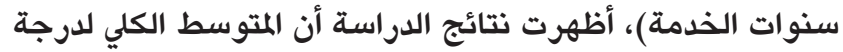

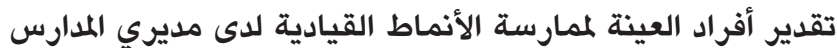

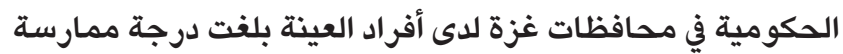

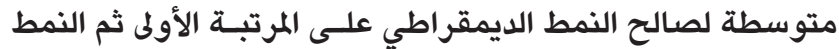
الأوتوقراطي ثم النمط المتسيب، ولا توجد فروق دالة إحصائياً

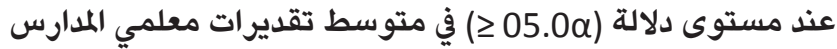
الحكومية بمحافظات غزة للأنماط القيادية السـائدة لدى مديرهم تعزى للمتغيرات التالية: (الجنس، المؤهل العلمي، سنوات الخدمة) قام علقم (r/r) بدراسة هدفت الى التعرف على العلاقة بين النمط القيادي لمديري المدارس الثانوية الحكومية، ودافعية المعلمين في محافظة رام الله والبيرة في (فلسطين) من وجهة نظر المعلمين، حيث تم استخدام العينة الطبقية العشوائية لتحقيق أهداف الدراسة، كما استخدم الباحث في هذه الدراسة المنهج

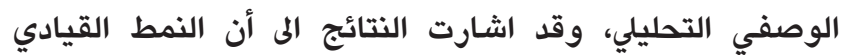
الأوتوقراطي هو النمط السائد لدى مديري المدارس الثانوية الحكومية في المحافظة، يليه النمط القيادي الديمقراطي في المرتبة الثانية، ثم النمط القيادي التسيبي في المرتبة الثالثة، وهناك علاقة ارتباط دالة إحصائي بين الأنماط القيادية ودافعية المتعلمين،

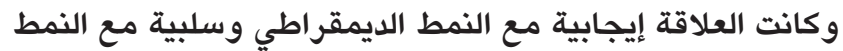
الأوتوقراطي والتسيبي.

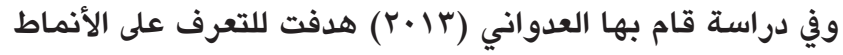

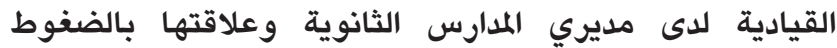
التنظيمية للمعلمين، حيث استخدمت الباحثة المنهج الوصفي الارتباطي، تكونت العينة من .7 معلم ومعلمة في المرحلة الثانوية في المناطق التعليمية بدولة الكويت للعام الدراسي

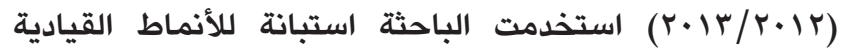
واستبانة الضغوط التنظيمية تم التأكد من دلالات صدقها وثباتها، اشارت النتائج الى ان نمط الإدارة السائد لدى مديري المدارس دلادئ الثانوية من وجهة نظر المعلمين كان النمط الديموقراطي ثم يليه

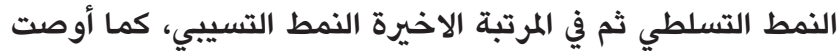
الدراسة بضرورة تعزيز النمط الديموقراطي والاهتمام بالبرامج التدريبية والاهتمام بالبيئة المادية للتعليم.

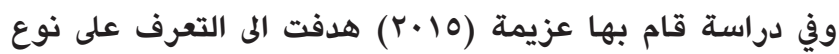
العلاقة بين النمط الاداري لمدراء المدارس بالرضا الوظيفي لمدارس المرحلة المتوسطة في محافظة بغداد، وتمثلت العينة بـ (YAr) مدرساً ثم استخدام مقياس الانماط القيادية، حيث اظهرت

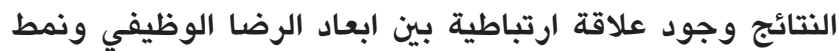
القيادة الادارية ونمط التوجيه والمتابعة لمقياس الانماط القيادية. وفي دراسة قام بها بارود (10) هدفت للتعرف على النمط القيادي الشائع لمديري مدارس المرحلة الاساسية الحكومية في
هامة أخرى، مثل: (النمط الديمقراطي، والنمط الأوتوقراطي)، أو

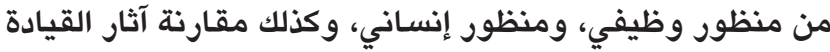

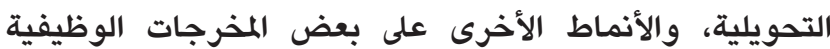
العامة مثل: رضا العاملين، وأدائهم، وقد أجريت الدراسة في

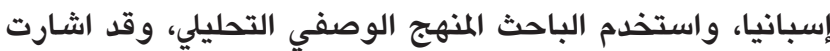
النتائج المى وجود علاقة ارتباطية قوية بين القيادة التحويلية، وكل التول من القيادة الديمقراطية، والقيادة الأوتوقراطية، أو من منظور

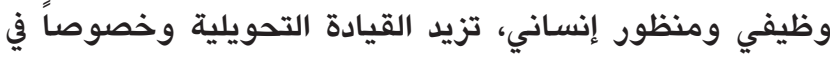

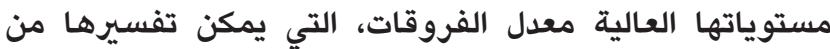

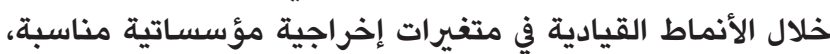
مثل: الجهد الإضافي، والرضا الوظيفي، وأداء العاملين.

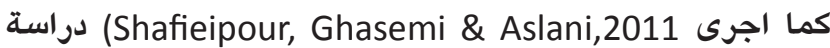
هدفت إلى إظهار العلاقة بين أساليب القيادة، وضغوط العمل على إلى إدارة المدرسة في دولة إيران، حيث يبدو أن الأنماط القيار العيادية للمديرين هي من بين العوامل التي تؤثر على مستويات التوتر لديهم، لأن وجود التوتر في مؤسسة، يمكن أن يؤثر على الحئ الحياة

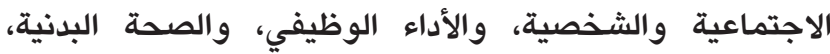

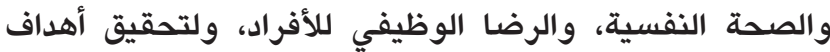
الدراسة استخدم الباحث المنهج المسحي، وقد اشـارت النتائج الى

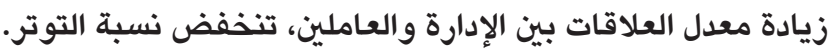

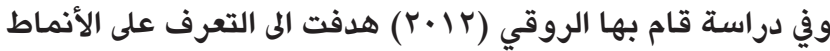

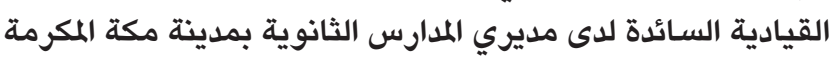
في المملكة العربية السعودية من وجهة نظر المعلمين، وعلاقتها

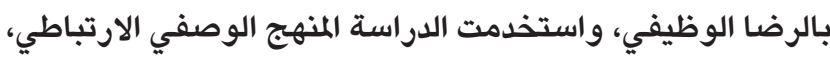

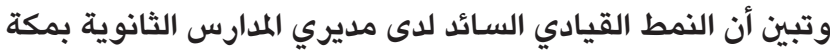

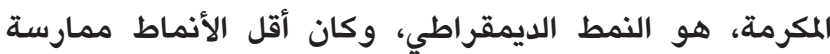

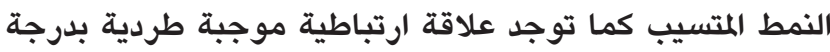
متوسطة بين درجة الرضا الوظيفي لدى المعلمين وبين النمط

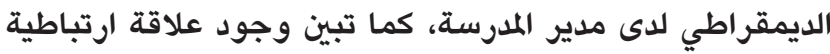
سالبة عكسية بين درجة الرضا الوظيفي لدى المعلمين وبين النمطين الأوتوقراطي والمتسيب لدى مدير المدرسة.

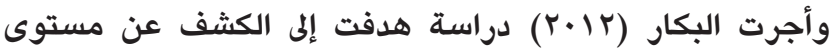
العدالة التنظيمية وعلاقته بمستوى الثقة التنظيمية من وجهة نظر المعلمين في المدارس الثانوية العامة في محافظة عمان، تكونت ولتهن العينة من (rVV) معلما تم اختيارهم بالطريقة العشوائية العنقودية، وقد استخدمت أداتان: الأولى لقياس مستوى ممارئ مارسة

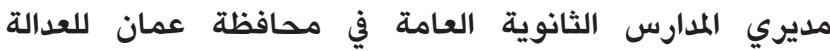
التنظيمية. والثانية لقياس مستوى الثقة التنظيمية في المدارس فئس الثانوية العامة، وأظهرت نتائج الدراسة أن مستوى ممارسة مديري المدارس الثانوية العامة في محافظة عمان افتهان للعدالة التنظيمية من وجهة نظر المعلمين كان متوسطا بشكل عام، وأن مستوى المدان ممارسة مديري المدارس الثانوية العامة في محافظة عمان مان للثقة التنظيمية كان متوسطا، ووجود علاقة موجبة ذات ذات دلالة إحصائية بين مستوى العدالة التنظيمية والثقة التنظيمية.

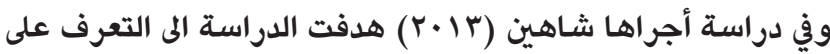


محافظة عجلون / الأردن وعلاقتها بالأداء المتميز لديهم علماً أن

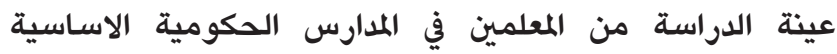
والثانوية وآرائهم حول الإدارة المدرسية في المؤسسات التعليمية المارسية الماسية

التي يعملون بها.

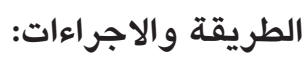

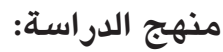

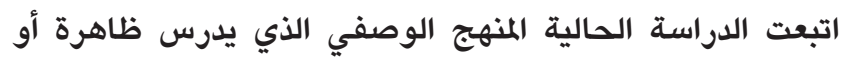

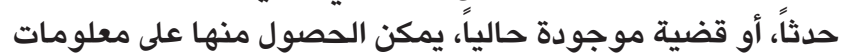
تجيب عن أسئلة الدراسة دون تدخل الباحثان فيه.

عينة الدراسة: الفي تألفت عينة الدراسة من معلمي المدارس الحكومية الثانوية البالغ

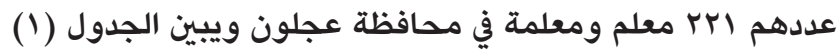
التكرارات والنسب المئوية لعينة الدراسة.

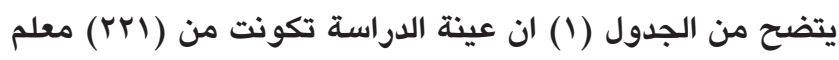

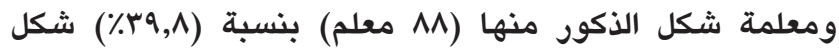

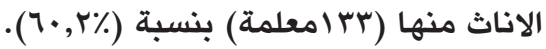

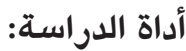
لتحقيق هدف الدراسة قام الباحثان بالرجوع إلى الأدب النظري

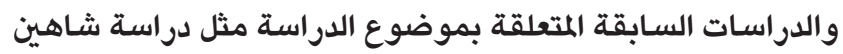

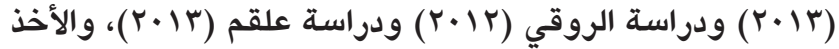

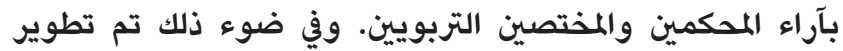

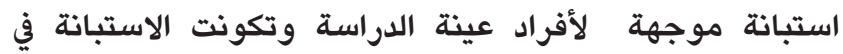
صورتها النهائية من (ع) ) فقرة موزعة على على بعدين هما: الأنماط

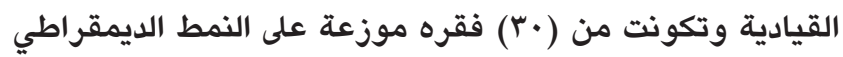

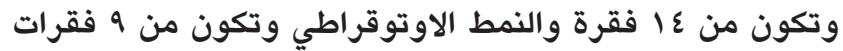
والنمط المتسيب وتكون من V فقرات الما الأداء المتميز للمديرين فتكون من (10) فقرة، واستخدام مقياس ليكرت (Likert Scale)

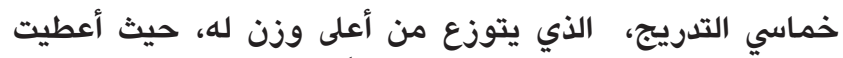

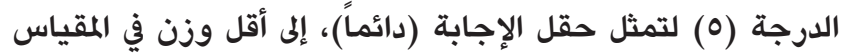

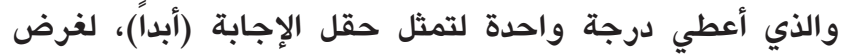
الإجابة عن أسئلة الدراسة واختبار فرضياتها.

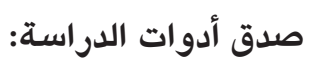

تم التحقق من صدق أداة الدراسة بطريقتين:

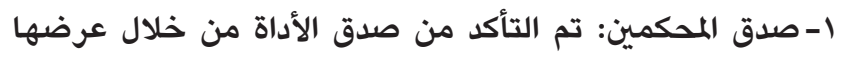

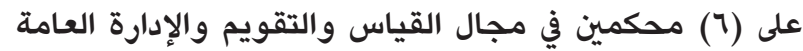

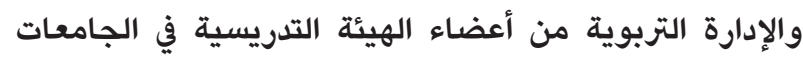
الأردنية الحكومية، وقد طلب الباحثان منهم إبداء ملاحظاتهم

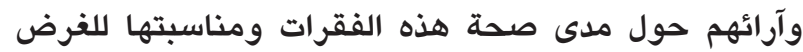

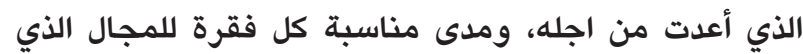

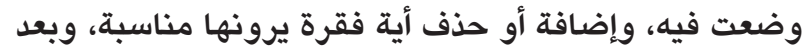
استعادة الاستبيانات تم تعديل الاستبانة في ضوء ملهات ملاحظات

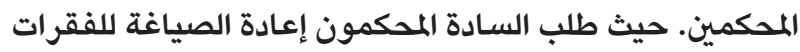

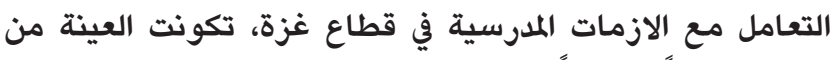

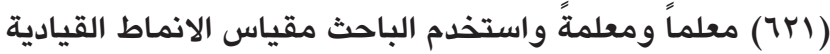

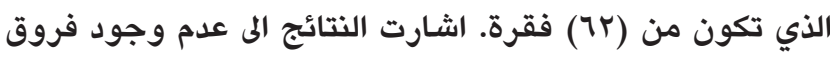

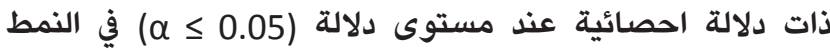

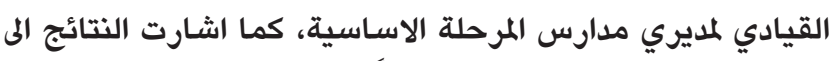

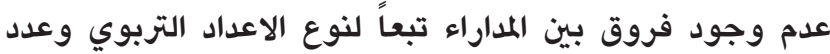

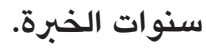
وفي دراسة قام بها سولاف (17) (17) هدفت للكشف عن أنماط القيادة التربوية وعلاقتها بالرضا الوظيفي لدى معلى معلمي المرحلة

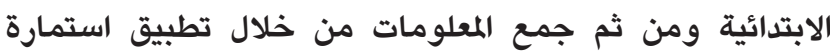
خاصة بالأنماط القيادية ومقياس الرضا الماتوان الوظيفي ثم التأكد من

دلالات صدقها وثباتها.

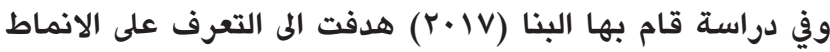
القيادية وعلاقتها بالسلوك الابداعي لدى العاملين في جهاز الأمن العنا

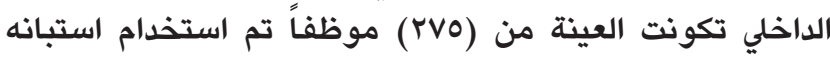

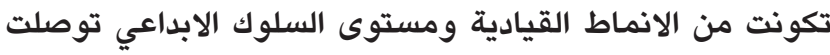
الدراسة الى ان النمط القيادي السائد هو نمط القياديادي النيادة المثالية ثم النمط الديموقراطي ثم النمط الاوتوقراطي ثم النمط الاجتماعي

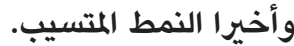

التعقيب على الدراسات السابقة لقد حظي موضوع علي علئ الأنماط القيادية في المدارس الحكومية باهتمام عدد كبير من الباحثين ويمكن تصنيف الدراسات السابقة الى ثلاثة

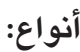

• دراسات كمية حول الأنماط القيادية في الجامعات والمؤسسات

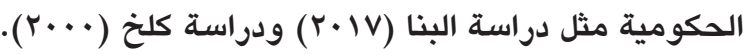

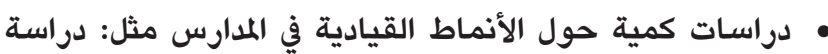

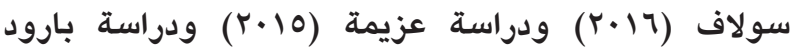

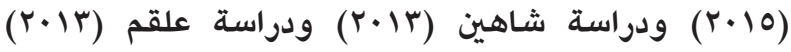

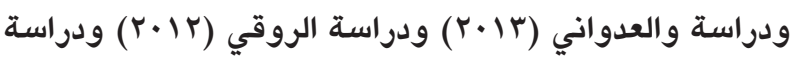

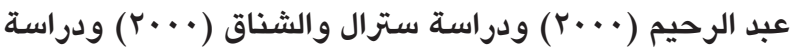

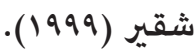
• دراسات تحليلية نوعية لواقع إدارة المدرسة كما في دراسة (لماسة Molero and) ودراسة دراسة (Shafiepour and etal, 2011)

(etal, 2007

كما يتضح من نتائج الدراسات السابقة أن هناك مدارس تتميز

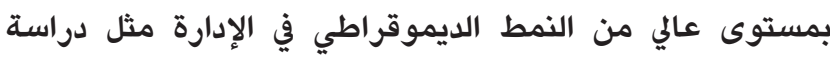

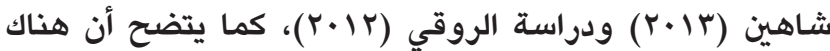

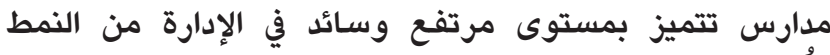

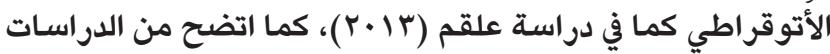
السابقة أن عوامل نجاح الإدارة التربوية يعتمد على الجهد الاضاضي

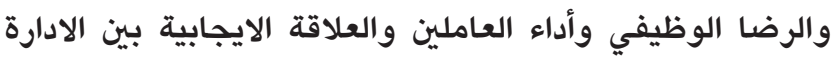

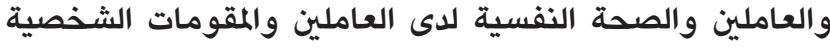

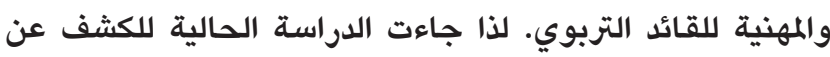

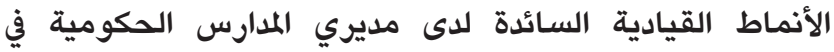


النتائج، ومن ثم مناقشتها وتفسيرها ووضع التوصيات والمقترحات.

متغيرات الدراسة:

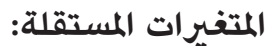
الجنس: المعلمين (الذكور، الاناث).

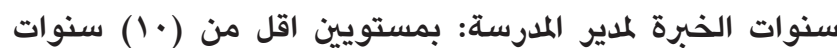
وأكثر من (· (1) سنوات. الدرجة العلمية لمدير المدرسة: وله أربع مستويات بكالوريوس دبلوم عالي ماجستير دكتوراه.

المتفيرات التابعة: - ابعة - النمط القيادي: وله ثلاث انماط الديموقراطي الأوتوقراطي المتسـاهل.

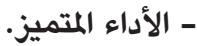

\begin{tabular}{|c|c|c|c|}
\hline النسبة & التكرار & الفئات & المتغير \\
\hline$r q, \wedge$ & $\wedge \wedge$ & ذكر & \multirow{2}{*}{ الجنس } \\
\hline $7 \cdot, r$ & rri & انثى & \\
\hline
\end{tabular}

الجدول (ז) معاملات الارتباط بين الفقرات والأنماط القيادية ككل

\begin{tabular}{|c|c|c|c|}
\hline معامل الإرتباط مع & رقم الفقرة & معامل الارتباط مع & رقم الفقرة \\
\hline ** qr. & 11 & ** VY. & 1 \\
\hline$\star * \wedge r$. & ir & ** Vา. & $r$ \\
\hline$* * V \cdot$. & ir & ** & $r$ \\
\hline$\star * \wedge 9$. & $1 \varepsilon$ & $\star \star \wedge \cdot$ & $\varepsilon$ \\
\hline ** 91. & 10 & ** VI. & 0 \\
\hline ** VV. & 17 & ** Vr. & 7 \\
\hline ** Vฯ. & IV & ** $\wedge$. & $v$ \\
\hline$\star * \wedge \varepsilon$. & 11 & ** 79. & $\Lambda$ \\
\hline$* * q$. & 19 & 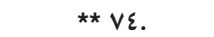 & 9 \\
\hline ** $\wedge$. & $r$. & ** q. & 1. \\
\hline
\end{tabular}

الجدول (ع) معاملات الارتباط بين الفقرات والأداء المتميز ككل

\begin{tabular}{|c|c|c|c|}
\hline معامل الارتباط & رقم الفقرة & معامل الارتباط & رقم الفقرة \\
\hline$* * 9$. & 11 & $\star \star \wedge \varepsilon$. & 1 \\
\hline$\star \star \wedge \uparrow$. & ir & ** VI. & r \\
\hline ** $\wedge r$. & ir & $* * 9$. & $r$ \\
\hline$* * \vee \vee$. & $1 \varepsilon$ & $* \star \wedge \varepsilon$ & $\varepsilon$ \\
\hline$\star * \wedge 0$. & 10 & $\star \star \wedge r$. & 0 \\
\hline
\end{tabular}

الجدول (0) معامل الاتساق الداخلي كرونباخ ألفا وثبات الإعادة للدرجة الكلية

\begin{tabular}{|c|c|c|}
\hline الاتساق الداخلي & ثبات الإعادة & المجال \\
\hline • Ar & $\cdot, \wedge \wedge$ & النمط القيادي \\
\hline$\cdot, \wedge 1$ & $\cdot, \wedge 0$ & الأداء المتميز \\
\hline
\end{tabular}

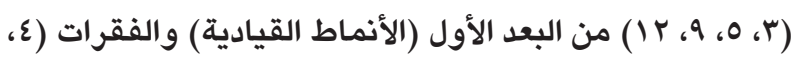
7، • (1) من البعد الثاني.

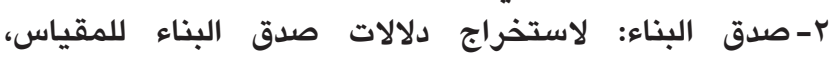
استخرجت معاملات ارتباط فقرات المقياس مع الدرجة الكلية

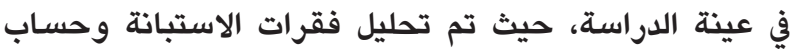

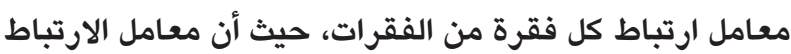

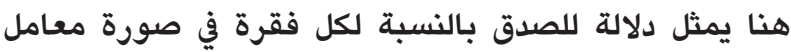

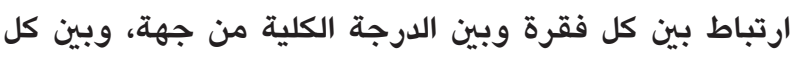
فقرة وبين ارتباطها بالمجال التي تنتمي إليه، وبين كل مجال

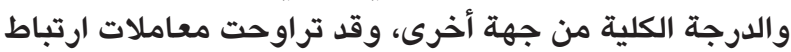

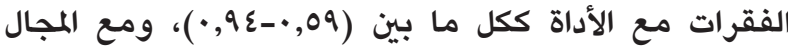

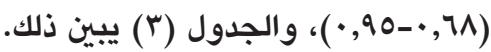

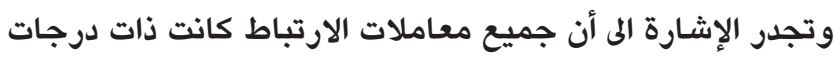
مقبولة ودالة إحصائيا، ولذلك لم يتم حذف أي من هذه الفقرات مدات. حيث يوضح الجدول (ع) معاملات الارتباط بين الفقرات والأداء

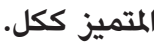

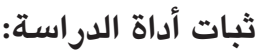
للتأكد من ثبات أداة الدراسة، فقد تم التحقق بطريقة الاختبار

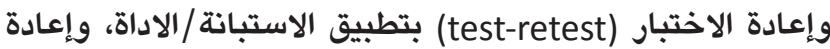
تطبيقها بعد أسبوعين على مجموعة من خارج عينة الدراسة

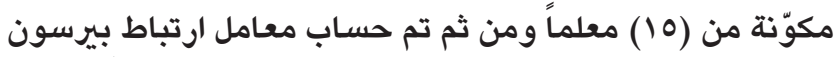
بين تقديراتهم في المرتين على أداة الدراسة ككل. وتم متم أيضاً حساب

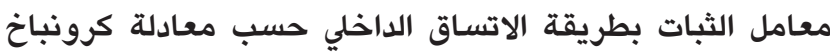
ألفا، والجدول (0) يبين معامل الاتساق الداخلي وفق معادلة كرونباخ ألفا وثبات الإعادة للمجالات والأداة ككل واعتبرت هذات هذاته

القيم ملائمة لغايات هذه الدراسة. كما يتضح من الجدول (0) ان معاملات الارتباط بين الفقرات

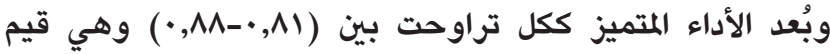
مقبولة لغايات الدراسة.

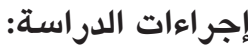

للتوصل إلى نتائج الدراسة قام الباحثان بالإجراءات الآتية: ا. تحديد هدف الدراسة والمتمثل بالكشف عن الأنماط القيادية

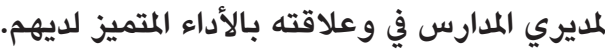
r. بناء أداة الدراسة في ضوء الأدب النظري والدراسـات وعات السابقة

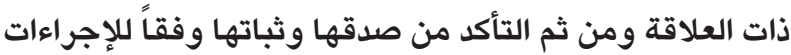
العلمية المتبعة في بناء الأدوات وحساب الصدق والثبات. r. اختيار أفراد العينة ثم مقابلتهم وشرح هدف الداء الدوات واسة لهم. ع. توزيع أداة الدراسة على أفراد عينة الدراسة.

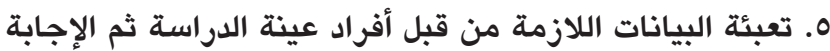
على فقرات الاداة كما يرونها معبرة عن وجهة نظرهم بكل صدق وموضوعية، وذلك بعد إحاطتهم علماً بأن إجاباتهم سرية ولن تستخدم إلا لأغراض البحث العلمي فقط.

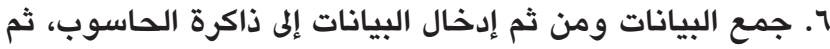
تم استخدام البرنامج الإحصائي (SPSS) لتحليلها واستخراج 
النمط الأوتوقراطي بنسبة (V,VI\%) الذي يركز على العمل واهمال العاملين ورضاهم ومشاركتهم في اتخاذ القرار او الاخذ بآرائهم

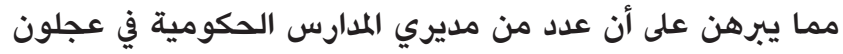

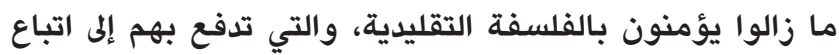
القوانين والحزم من وجهة نظرهم لأنه أفضل من تفويض تالفي

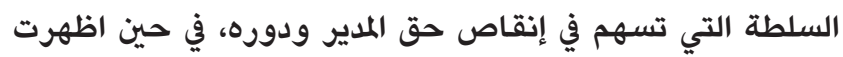

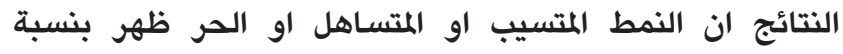

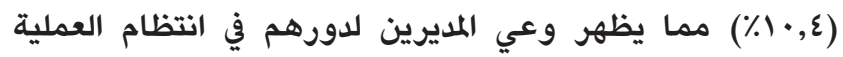

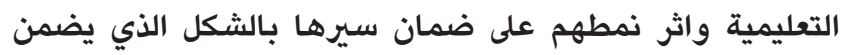

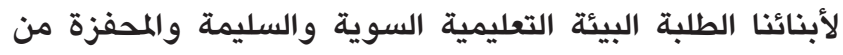

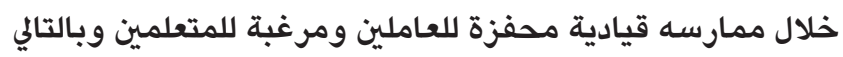

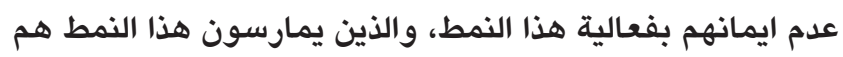
الذين يسعون إلى إرضاء العاملين وهو كمالية والذين يعتقدون النهارئ الأداء

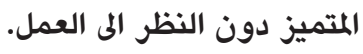

السؤال الثاني: ما مستوى الأداء المتميز لدى مديري المدارس في

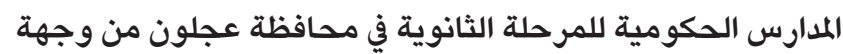

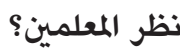
للإجابة عن هذا السؤال تم استخراج المتوسطات الحسابية

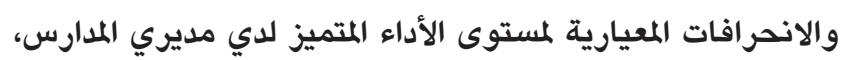

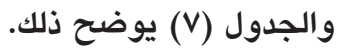

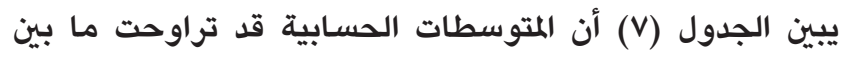

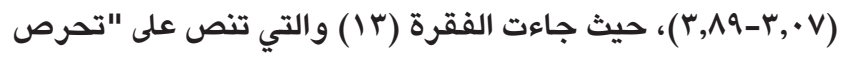

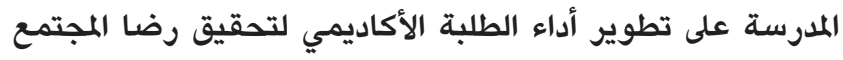

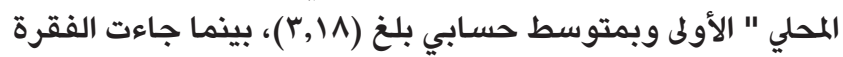

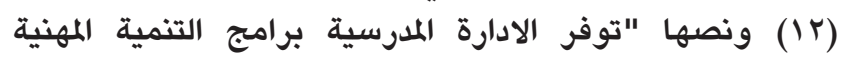

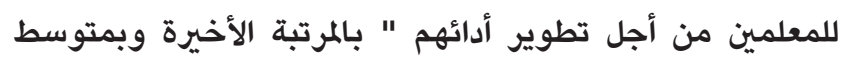

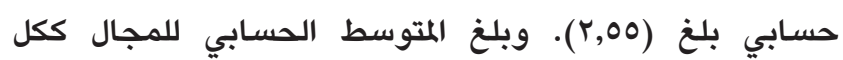

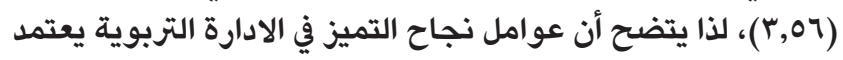

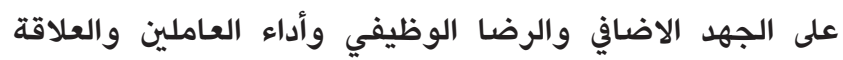

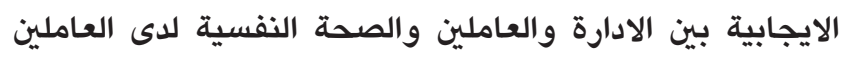
والمقومات الشخصية والمهنية للقائد التربوي.

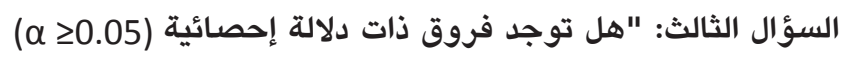

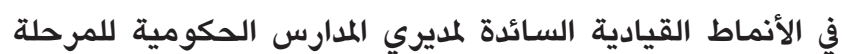

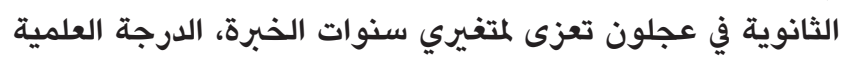

لمدير المدرسة من وجهة نظر المعلمين؟ تلوئ. للإجابة عن هذا السؤال تم استخراج المتوسطات المسابية المسابية والانحرافات للأنماط القيادية المتبعة في المدارس المات الحكومية

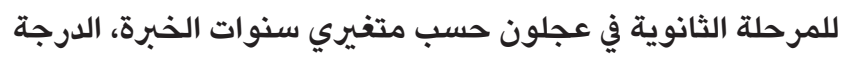

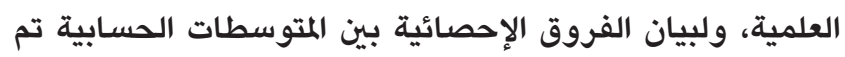

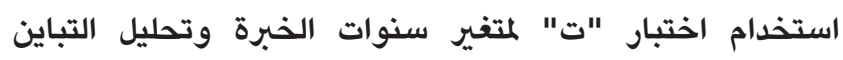
الأحادي لمتفير الدرجة العلمية، كما في الجدول (^، (^).

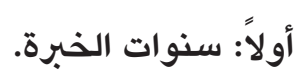

يتبين من الجدول (^) عدم وجود فروق ذات دلالة إحصائية تعزى
نتائج الدراسة ومناقشتها: هدفت هذه الدراسة للتعرف على طبيعة العلاقة بين النمط القياديادي

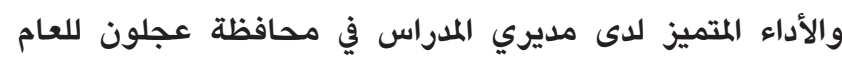

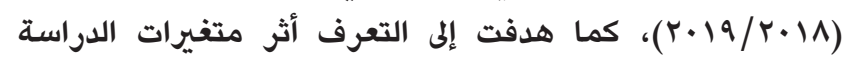

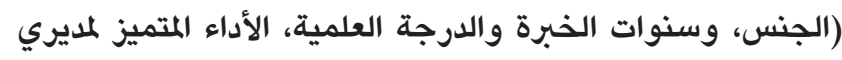

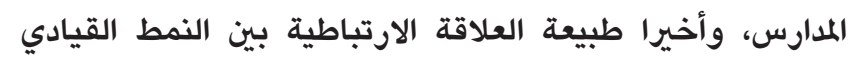

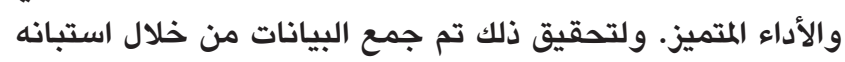

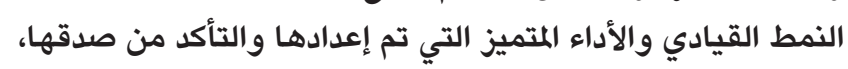

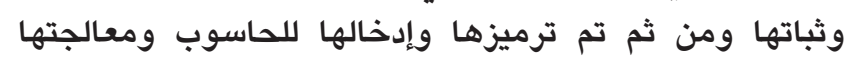

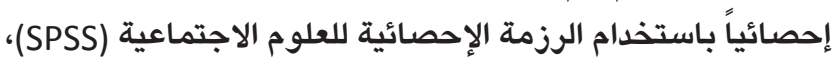
وفيما يلي نتائج الدراسة تبعاً لتسلسل الأسئلة: السؤال الاول: "ما الأنماط القيادية لمديري المدارس الحكومية

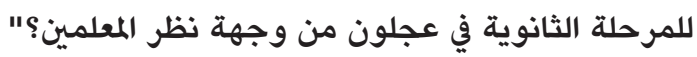

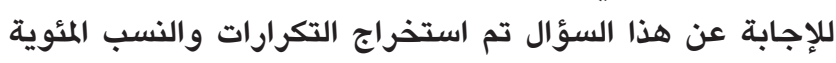

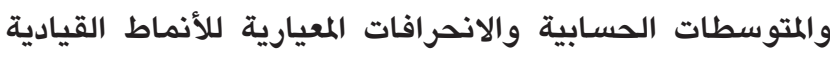

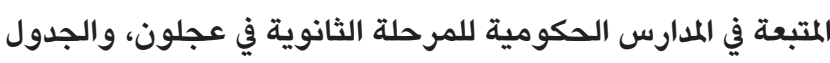
(7) يوضح ذلك.

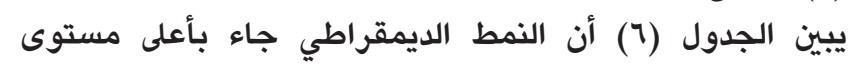

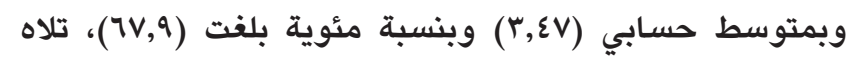

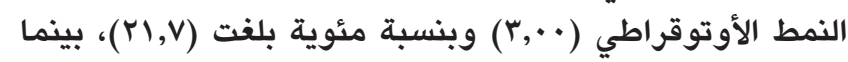

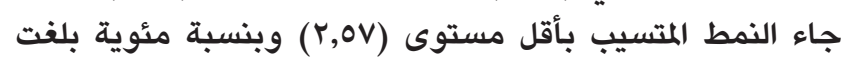

يستنتج الباحثان أن النمط الديموقراطي هو الاكثر انتشاراً بين

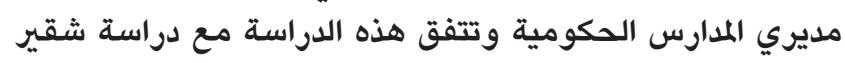

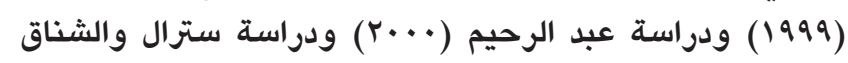

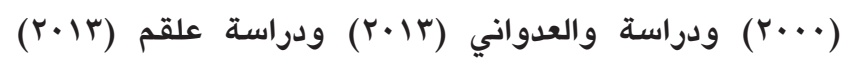

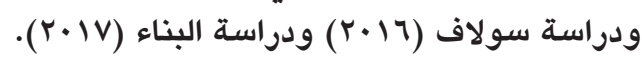

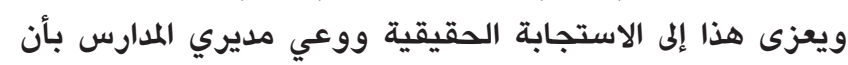
النمط الديموقراطي هو الاكثر فعالية في إدارة كافة الإية النظم المنبثقة

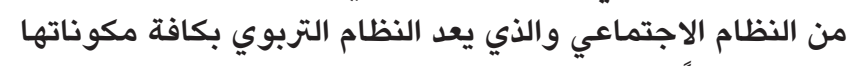

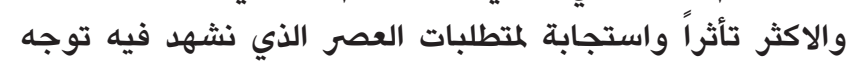

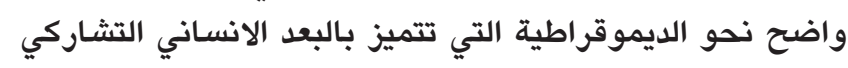

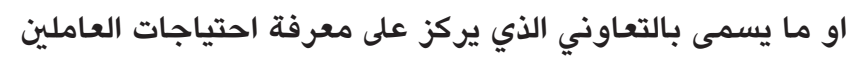

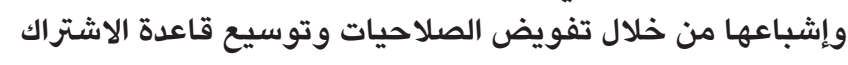
في اتخاذ القرارات ووضع الأهداف، في حين أظهرت النتائج ظهور

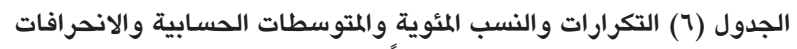
المعيارية للأنماط القيادية الأكثر شيوعاً المتبعة في المدارس الحكوسات المكومية للمرحلة

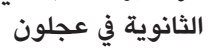

\begin{tabular}{|c|c|c|c|c|}
\hline المعياري & الحسابي & النسبة & التكرار & النمط \\
\hline OET. & $r, \varepsilon V$ & $7 V, 9$ & 10. & ديمقراطي \\
\hline ह१५. & $r, \cdot \cdot$ & rI,V & $\varepsilon \wedge$ & أوتوقراطي \\
\hline \multirow[t]{2}{*}{ TEO. } & r,OV & $1 \cdot, \varepsilon$ & rr & المتسيب \\
\hline & & $1 \ldots$ & TrI & المجموع \\
\hline
\end{tabular}


فئات متغير الدرجة العلمية. ولبيان دلالة الفروق الإحصائية بين المتوسطات الحسابية تم

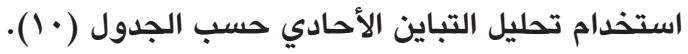

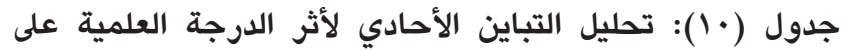

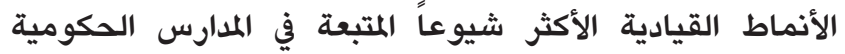
للمرحلة الثانوية في عجلون الأنيادية
لسنوات الخبرة وتتفق هذه الدراسة مع دراسة شقير (1999)

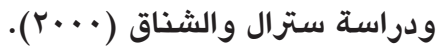

ثانياً: الدرجة العلمية

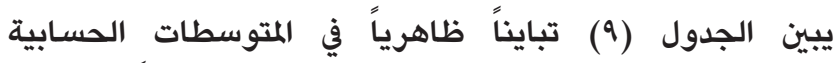

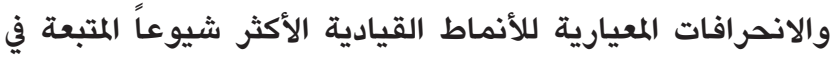

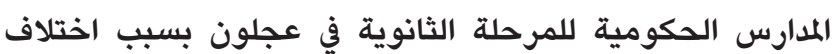

الجدول (V) المتوسطات الحسابية والانحرافات المعيارية لفقرات لمستوى الأداء المتميز لدي مديري المدارس مرتبة تنازلياً حسب المتوسطات الحسابية

\begin{tabular}{|c|c|c|c|c|c|}
\hline 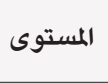 & الانحياري & الحسابي & 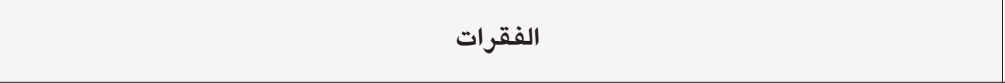 & 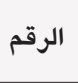 & 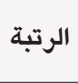 \\
\hline عالي & וזי (14. & $r, \wedge q$ & تحرص المدرسة على تطوير أداء الطلبة الاكاديمي لتحقيق رضا المجتمع المحلي & ir & 1 \\
\hline عالي & vาl. & $r, \mathrm{vV}$ & تشجع الادارة المدرسية على إعداد النشرات التربوية من اجل تحسين العملية التعليمية التعلمية & $\circ$ & r \\
\hline عالي & $77 v$. & 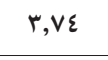 & تحرص الادارة المدرسة على تفعيل تبادل الزيارة بين المعلمين لتطوير الأداء & r & r \\
\hline عالي & vrq. & $r, \vee \varepsilon$ & تحرص الادارة المدرسة على تشجيع المبادرات الابداعية للمعلمين & $\varepsilon$ & $\varepsilon$ \\
\hline عالي & $\wedge \neg \varepsilon$. & $r, \vee \varepsilon$ & تحرص الادارة المدرسية على الاستفادة من تجارب المدارس الريادية & 1 & $\circ$ \\
\hline عالي & 9 9r. & r, iv & تحرص الادارة المدرسية على التقييم المستمر لخطط المدرسة من أجل تحقيق التميز & r & 1 \\
\hline عالي & $\wedge 97$. & r,09 & تحرص الادارة المدرسة على توفير ثقافة تنظيمية تشجع المنافسة بدلا من الصراع التنظيمي & 9 & $v$ \\
\hline عالي & Aro. & 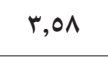 & تحرص الادارة على بث ثقافة التميز والابداع بدلا من الاسلوب التقليدي في العمل & 11 & $\wedge$ \\
\hline عالي & TV・. & r,०० & تحرص الادارة المدرسية على التقييم الدور لأداء العاملين في المدرسة لتحقيق الأداء المبدع & 10 & 9 \\
\hline 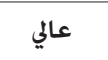 & $90 \cdot$ & r,or & تشجع الادارة المدرسية مبدأ النقد البناء لتلافي أوجه القصور في الأداء & \ع & 1. \\
\hline متوسط & 900. & $r, \varepsilon \wedge$ & تحرص الادارة على المشاركة بالمسابقات التربوية من أجل تحقيق الريادية وليس مجرد المشية & 1. & 11 \\
\hline 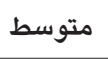 & VVI. & $r, \varepsilon$. & توفر الادارة الامكانات المدرسية المادية والمعنوية لتطوير أداء المعلمين والطلبة & $\checkmark$ & ir \\
\hline متوسط & 1,109 & $r, r \cdot$ & تعتمد الادارة المدرسة اسلوب الابتكار والابداع لتحقيق التميز & 1 & ir \\
\hline 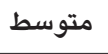 & 1,199 & $r, r v$ & توفر الادارة للعاملين فرصة المشاركة في إبداء الراي في القضايا التي تهم المدرسة & $\wedge$ & ।ع \\
\hline متوسط & $1, \cdot \varepsilon q$ & $r, \cdot v$ & توفر الادارة المدرسية برامج التنمية المهنية للمعلمين من أجل تطوير أدائهم & ir & 10 \\
\hline عالي & $\varepsilon \wedge \cdot$. & $r, 07$ & 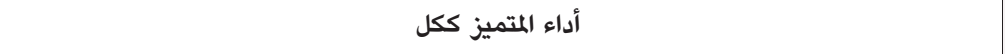 & & \\
\hline
\end{tabular}

الجدول (9) : المتوسطات الحسابية والانحرافات المعيارية للأنماط القيادية الأكثر شيوعاً المتبعة في المدارس الحان الحكومية المعيارية

\begin{tabular}{|c|c|c|c|}
\hline المعياري & الحسابي & الفئات & النمط \\
\hline ґ^o. & $r, 00$ & بكالوريوس & \multirow{5}{*}{ الديمقراطي } \\
\hline ०^т. & $r, \varepsilon 1$ & دبلوم عال & \\
\hline TVr. & $r, \varepsilon$. & ماجستير & \\
\hline$\varepsilon ૦ \wedge$. & r,or & دكتوراه & \\
\hline oEr. & $r, \varepsilon V$ & المجموع & \\
\hline Err. & $r, \cdot r$ & بكالوريوس & \multirow{5}{*}{ الأوتوقراطي } \\
\hline$\varepsilon \curlyvee \wedge$. & $r, 97$ & دبلوم عال & \\
\hline $0 \wedge 9$. & $r, v 7$ & ماجستير & \\
\hline$\varepsilon \cdot \varepsilon$. & $r, r \varepsilon$ & دكتوراه & \\
\hline हq५. & $r, \cdot \cdot$ & المجموع & \\
\hline $1 \wedge 0$. & $r, 79$ & بكالوريوس & \multirow{5}{*}{ النمط المتساهل } \\
\hline oहr. & r,or & دبلوم عال & \\
\hline 779. & r, rT & ماجستير & \\
\hline ТЕץ. & $r, V V$ & دكتوراه & \\
\hline $7 \varepsilon 0$. & r,OV & المجموع & \\
\hline
\end{tabular}

الجدول (^) المتوسطات الحسابية والانحرافات المعيارية واختبار "ت" لأثر سنوات الخبرة على الأن الأنماط القيادية

\begin{tabular}{|c|c|c|c|c|c|c|c|}
\hline الإحصائية & لدرجات & "قيمة & الالانحراف & الحسابي & العدد & سنوات & النمط \\
\hline \multirow{2}{*}{$7 \cdots$} & \multirow{2}{*}{ riq } & \multirow{2}{*}{ ort. } & ¿97. & $r, \varepsilon q$ & 77 & سنوات من & \multirow{2}{*}{ الديمقراطي النمط } \\
\hline & & & ort. & r,£० & 100 & سنوات فشر & \\
\hline \multirow[b]{2}{*}{ จ^ฯ. } & \multirow[b]{2}{*}{ KIq } & \multirow[b]{2}{*}{ rVI. } & ₹70. & $r, 99$ & 77 & سنوات من 1 اقن & \multirow{2}{*}{ الأوتوقر اططي } \\
\hline & & & 0.0. & $r, \cdot 1$ & 100 & سنوات عثر & \\
\hline \multirow{2}{*}{ ¿VI. } & \multirow{2}{*}{ KIq } & \multirow{2}{*}{ Vrr. } & $\vee \cdot \Lambda$. & r,or & 77 & سنو من • & \multirow{2}{*}{$\begin{array}{c}\text { المتساهل } \\
\text { النمطل }\end{array}$} \\
\hline & & & TIV. & r,0q & 100 & سنوات عثر & \\
\hline
\end{tabular}


السؤال الرابع" هل هناك علاقة ارتباط ذات دلالة إحصائية عند

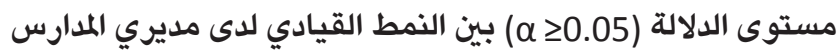

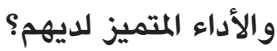

وتم اشتقاق الاسئلة التالية من السؤال السـابق: () هل يوجد أثر لنمط القيادة الديمقراطي على مستوى الأداء

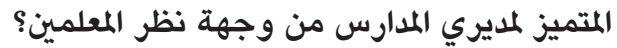
للإجابة عن السؤال هذا السؤال، تمت صياغته على شكل فرضئ فرضية

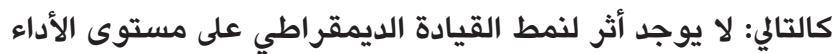

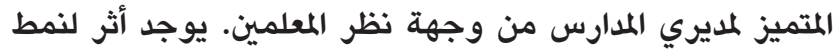

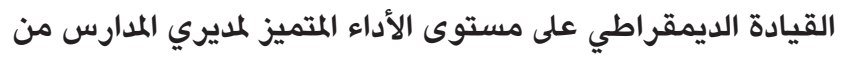
وجهة نظر المعلمين. ولاختبار هذه الفرضية تم استخدام تحليل الانحدار المتعدد، حيث تم استخراج قيم (بيتا) وقيم (T) ومستوى ولمانه

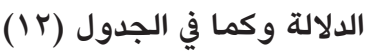

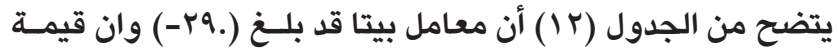

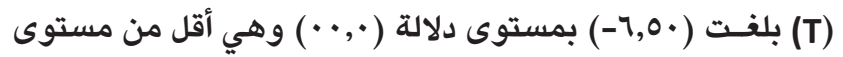

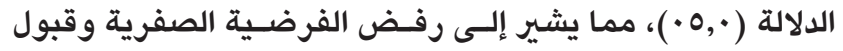

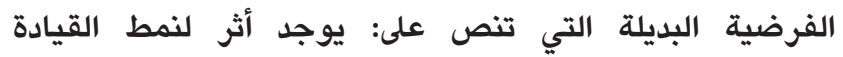
الديمقراطي على مستوى الأداء المتميز لمديري المدارس من وجهة نظر المعلمين وتتفق هذه النتيجة مع نتيجة دراسة العدئي

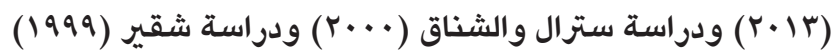

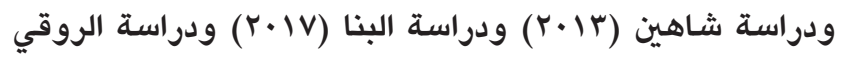

ويمكن تفسير هذه النتيجة بأن استخدام رؤساء

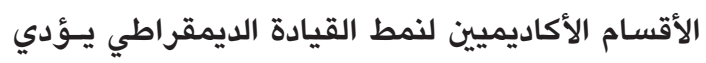

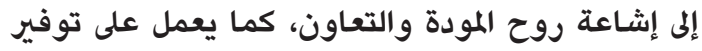

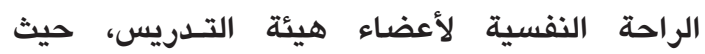
يشعرون بأن جو العمل يملؤه الحب والمودة، ولا يوجد

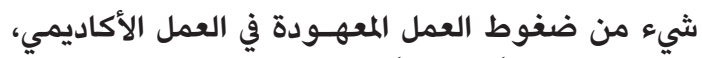

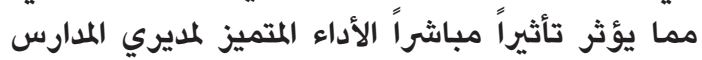

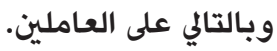
r) هل يوجد أثر لنمط القيادة المتسيب على مستوى الأداء المتميز لمديري المدارس من وجهة نظر

المعلمين؟ الاءد

وللإجابة عن هذا السؤال، تمت صياغته على شكل فرضية التالي: لا يوجد أثر لنمط القيادة المتسيب على الأداء المتميز لملديري المدارس من وجهة نظر المعلمين، يوجد أثر لنمط القيادة المتسيب على مسستوى الأداء المتميز لمديري المدارس من وجهة نظر المعلمين،

الجدول (T) (I) قيم (بيتا) والإحصائي (T) ومستوى الدلالة

\begin{tabular}{|c|c|c|}
\hline S.G & T & Beta \\
\hline 0.00 & $6.50-$ & $.29-$ \\
\hline
\end{tabular}

الجدول (rا) قيم (بيتا)

\begin{tabular}{|c|c|c|}
\hline S.G & T & Beta \\
\hline 0.00 & 4.63 & 0.20 \\
\hline
\end{tabular}

تبين من الجدول (•() وجود فروق ذات دلالة إحصائية عند

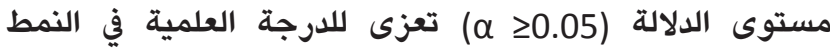
الأوتوقراطي، والنمط المتساهل، ولبيان الفروق الدالة إحصائيا

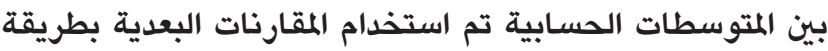

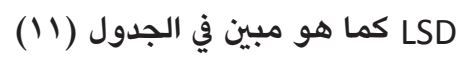
a) يتبين من الجدول (11): وجود فروق ذات دون دلالة إحصائية

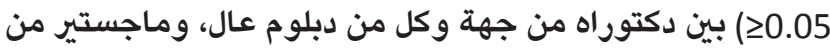
جهة اخرى وجاءت الفروق لصالح دكتوراه، كما تبين وجود دئورد

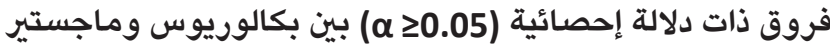

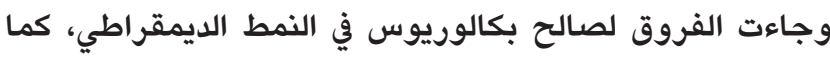
وجود فروق ذات دلالة إحصائية (0.05 $\alpha$ (2) بين الماجستير من جهة وكل من البكالوريوس، والدكتوراه من جهة اخرى ورجاء وجاءت الفروق لصالح كل من البكالوريوس، والدكتوراه في النمط المتسـاهل ولا تتفق هذه الدراسة مع دراسة شقير(999 (1) ودراسة

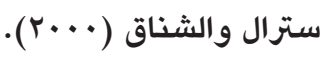

ويستنج الباحثان أن مديري المدارس من حملة شهادة الدكتوراه يمارسون النمط الأوتوقراطي رغبة منهم في إظهار الفـارق العلمي مدي المدي بينهم وبين المعلمين مما يعطيهم وحسب نظرتهم، القائد الذي يستأثر بجميع السلطات ويرسم خطة العمل وطرق تنفيذها ويحرك الجماعة كما يشاء وهو بذلك يحد من حيوية ونشاط ودئ العاملين معه ويحاول عدم خلق قيادات جديدة.

الجدول (• (1): تحليل التباين الأحادي لأثر الدرجة العلمية على الأنماط القيادية الأكثر شيوعاً

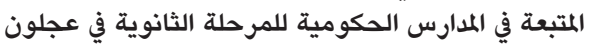

\begin{tabular}{|c|c|c|c|c|c|c|}
\hline الإحصائية الدلالة & قيمة ف & متوسط المربعات & لدرجات & المربعات & المصدر & النمط \\
\hline ૫દ.. & 1,110 & $\begin{array}{l}\text { rrq. } \\
\text { rqo. }\end{array}$ & $\begin{array}{l}\text { r } \\
\text { riv } \\
\text { rto. }\end{array}$ & $\begin{array}{l}9 \wedge 7 . \\
7 r, 909 \\
7 \varepsilon, q \varepsilon 0\end{array}$ & داخل المجموعات المجموعات & الديمقراطي النمط \\
\hline$\cdots$ & $9, \varepsilon 79$ & $\begin{array}{l}\text { r.,OV } \\
\text { rIV. }\end{array}$ & $\begin{array}{l}\text { r } \\
\text { riv } \\
\text { re. }\end{array}$ & $\begin{array}{l}\text { T,IVI } \\
\varepsilon V, \mid \text { TV } \\
\text { or,r.A }\end{array}$ & داخل المجموعات المجموعات & الأوتوقراطي النمط \\
\hline$\cdots r$. & $0, \cdot r 7$ & 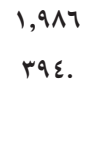 & $\begin{array}{l}\text { r } \\
\text { riv } \\
\text { rr. }\end{array}$ & $\begin{array}{l}0,909 \\
10,09 . \\
91,00 .\end{array}$ & داخل المجموعات المجموعات & المتسـاهل النمط \\
\hline
\end{tabular}

الجدول (I) المقارنات البعدية بطريقة LSD لأثر الدرجة العلمية على النمط الأوتوقراطي

\begin{tabular}{|c|c|c|c|c|c|c|}
\hline دكتوراه & ماجستير & دبلوم عال & بكالوريوس & المستوسطي المسي & العلمية & النمط \\
\hline & & & & $r, \cdot r$ & بكالوريوس & \multirow{4}{*}{ الأوتوقراطي النمطي } \\
\hline & & & $1 \cdot$ & $r, 97$ & دبلوم عال & \\
\hline & & $r \cdot$. & *r. & $r, V T$ & ماجستير & \\
\hline & \multirow[t]{4}{*}{$\star \varepsilon \wedge}$. & *ץ^. & iv. & $r, r \varepsilon$ & دكتوراه & \\
\hline & & & & $r, 79$ & بكالوريوس & \multirow{4}{*}{ 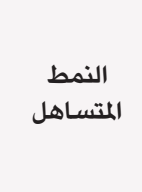 } \\
\hline & & & 17. & r,or & دبلوم عال & \\
\hline & & rI. & *rv. & T,HT & ماجستير & \\
\hline & * $\varepsilon$ ०. & rE. & $\cdot \wedge$. & $r, V V$ & دكتوراه & \\
\hline
\end{tabular}




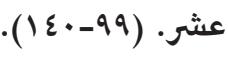

البدري، طارق عبد الحميد ( ( •.ب). الاساليب القيادية والإدارة في المؤسسات التعليمية، ط ا، عمان، الأردن، دار الفكر للطباعة

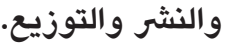

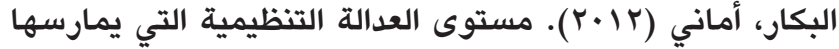

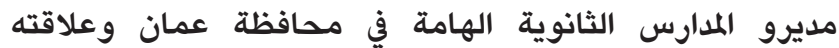
بمستوى الثقة التنظيمية في مدارسهم من وجهة نظر المعلمين. رسالة ماجستير غير منشورة، جامعة الشرق الأوسط، عمان،

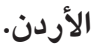

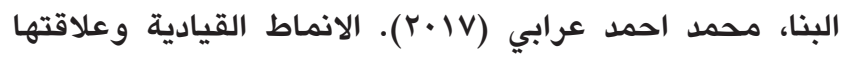

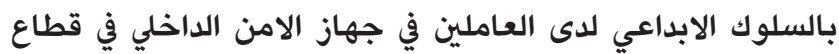
غزة، رسالة ماجستير، جامعة الاقصى، غزة.

حريم، حسن (ך · ·ץ). مبادئ الإدارة الحديثة النظريات العمليات الإدارةة وظائف المنظمة. عمان، الأردن، دار حامد للنشر.

حمود، كاظم خضير (· ( + ). منظمة المعرفة، عمان، الأردن، دار صفاء.

الروقي، عبد الله بن عايض (r (†). الأنماط القيادية لمديري

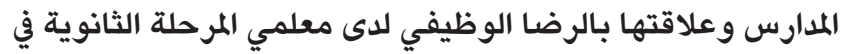
مدينة مكة المكرمة، رسالة ماجستير غير منشورة، جامعة أم القرى، جدة، السعودية.

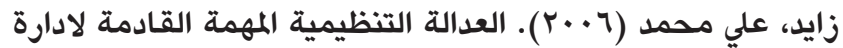

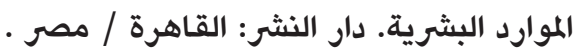

سولاف، حماده (T 1 • ( ). أنماط القيادة التربوية وعلاقتها بالرضا الوظيفي لدى معلمي المرحلة الابتدائية، رسالة ماجستير، جامعة العربي بن مهيدي، ام البوقي/ الجزئئر.

شاهين، نرمين كمال (rا.ب). الأنماط القيادية لدى مديري المدارس الحكومية بمحافظات غزة وعلاقتها بتعزيز ثقافة الإنجاز، رسالة ماجستير غير منشورة، الجامعة الإسلامية، غزة. شقير، يسرى حسين (1999). إدراك المعلمين للنمط القيادي لمديري المدارس الحكومية في محافظة بيت لحم وعلاقته باتجاهاتهم نحو مهنة التدريس، رسالة ماجستير غير منشورة، جامعة القدس/ فلسطين.

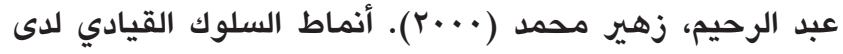
مديري المدارس الاساسية في محافظة اربد وعلاقتها بالرضا الوظيفي للمعلمين من وجهة نظر المعلمين، رسالة ماجستير،

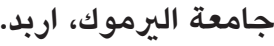

العدواني، حنان (rا+r). الأنماط القيادية لدى مديري المدارس الثانوية في دولة الكويت وعلاقتها بالضغوط التنظيمية للمعلمين
ولاختبار هذه الفرضة تم استخدام تحليل الانحدار المتعدد، حيث تم استخراج قيم (بيتا) وقيم (T) ومستوى الدلالة كما في الجدول

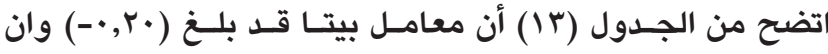

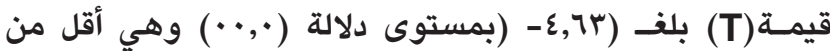

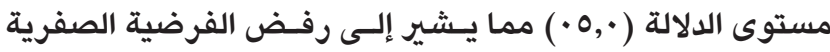
وقبول الفرضية البديلة التي نصت على: يوجد أثـر لــنمط القيـادة

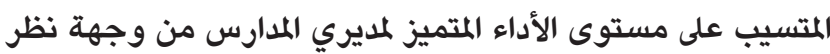

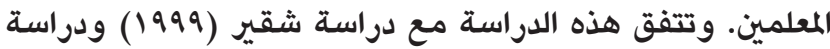

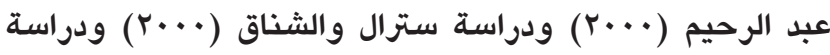

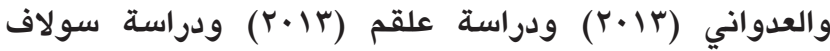

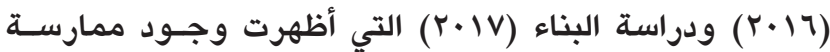

ضعيفة لنمط القيادة المتسيبة. ويمكن تفسير هذه النتيجة الى أن استخدم هذا النمط القيادي من

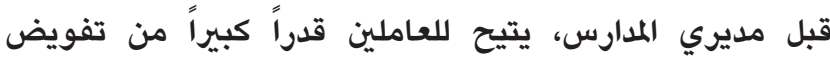

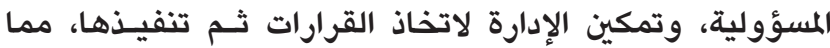

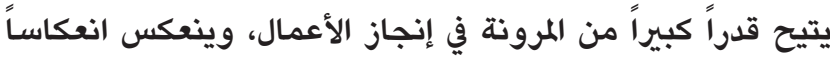

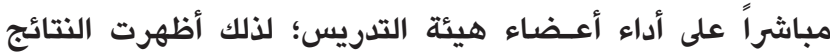
وجود أثر لذلك النمط على الأداء المتميز لمديري المدارس.

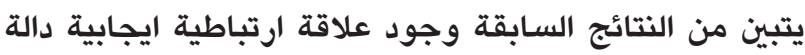

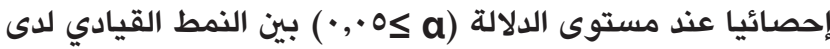
مديري المدارس في منطقة عجلون والأداء المتميز.

التوصيات

في ضوء النتائج السابقة توصي الدراسة بالآتي:

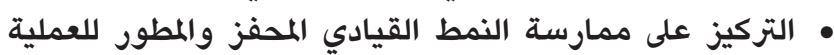

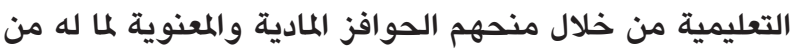

آثار إيجابية على أدائهم الوظيفي.

• عقد الدورات التدريبية لمديري المدارس لتوعيتهم بأهمية التهية اساليب وأنماط القيادة في الارتقاء بمستوى المدرسة وتمديل

وتميز اداء مديريها. • إجراء المزيد من الدراسـات حول الأداء المتميز وانعكاساته على على العملية التعليمية بكافة عناصرئ المردا. • إجراء المزيد من الدراسات النقدية حول إثر النمط الاتوقراطي والنمط المتسيب في الادارة المدرسية.

$$
\text { المراجح }
$$

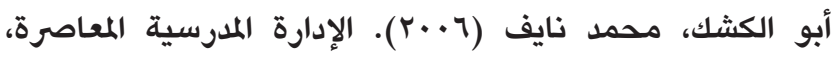
عمان، الأردن، دار جرير للنشر والتوزيع

أحمد، حافظ فرج؛ حافظ، محمد صبري (r + . ب). إدارة المؤسسات التربوية، جمهورية مصر العربية، القاهرة، عالم الكتب.

بارود، خالد يوسف (10 (†). النمط القيادي لمديري مدارس

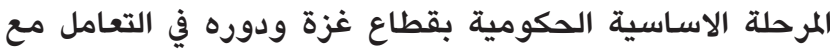

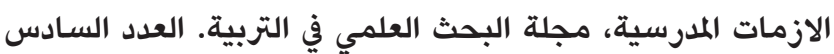


Moye, M., Henkin, A.and Egley, R. (2005). Teacherprincipal relationships: exploring linkage between empowerment and interpersonal trust. Journal of Educational Administration, 43(3), 260277.

Richard,D.(2008),"New Era of Management" Thomon, soul-Western Australia.

Robbins Stephen P. And Coulter, Merry,(2009). Management,10th Ed.New Jersy.Person,USA.

Shafieipour.V, Ghasemi.M \& Aslani .M.(2011). The Effects of Leadership styles on the stress of school's directors. Social and Behavioral Sciences Journal .28 $(82-86)$.
من وجهة نظرهم، رسالة ماجستير، جامعة الشرق الاوسط/

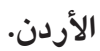

عزيمة، سالم رشيد (10 (Y). النمط القيادي الاداري لمديري

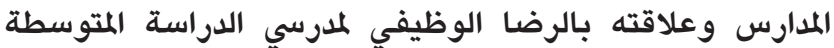

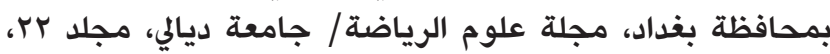

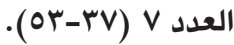

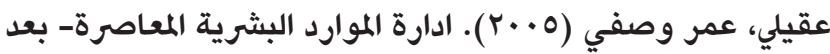

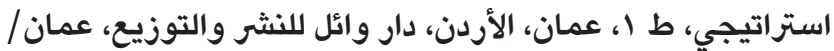

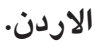

العلاق، بشير (^^•ץ). الإدارة الحديثة نظريات ومفاهيم، عمان،

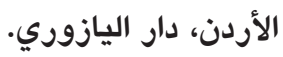

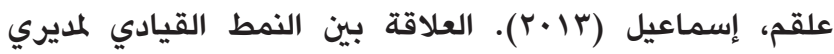
المدارس الثانوية الحكومية ودافعية المعلمين في محافظة راعي رام الله والبيرة من وجهة نظر المعلمين، رسالة ماجستير غير منشورة،

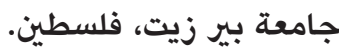

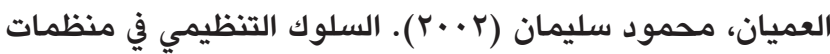
الاعمال. ط ا، دار وائل للطباعة والنشر، عمان، الأردن.

فهمي، محمد سيف الدين؛ محمود، حسن عبد المالك (ب991)). تطوير الإدارة المدرسية في دول الخليج العربية، مكتب التربية العربي لدول الخليج، الرياض.

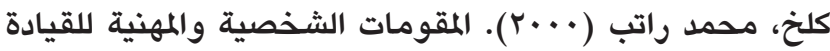

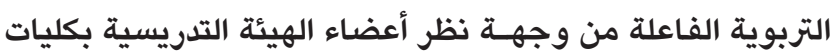
التربية في محافظات غزة. رسالة ماجستير، الجامعة الإسلاميةغزة. المدهون، محمد إبراهيم؛ العجرمي، محمد عبد ربه. (1I) (1).

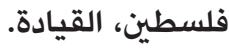

Koontz H, \& Weirich, (1988). International Management edition 9. Singapore: McGraw-Hill.

Mohammad, Musli, Mann, Robin, Grigg, Nigel and Wagnera, Ju"rgen P,(2011)," Business Excellence Model: An overarching framework for managing and aligning multiple organizational improvement initiatives".

Molero.F, Cuadrado.I, Navas. M, \& Morales.J.(2007). Relations and Effects of TransformatinalLeadership:A Comparative Analysis with Traditional Leadership Styles The Spanish Journal of Psychology, Vol.10, No.2, (358-368). 